University of Nebraska - Lincoln

DigitalCommons@University of Nebraska - Lincoln

Faculty Publications, Department of Psychology

Psychology, Department of

4-30-2007

\title{
Behavioral and neuropharmacological characterization of nicotine as a conditional stimulus
}

Jennifer E. Murray

University of Nebraska-Lincoln, jem98@cam.ac.uk

Rick A. Bevins

University of Nebraska-Lincoln, rbevins1@unl.edu

Follow this and additional works at: https://digitalcommons.unl.edu/psychfacpub

Part of the Psychiatry and Psychology Commons

Murray, Jennifer E. and Bevins, Rick A., "Behavioral and neuropharmacological characterization of nicotine as a conditional stimulus" (2007). Faculty Publications, Department of Psychology. 223.

https://digitalcommons.unl.edu/psychfacpub/223

This Article is brought to you for free and open access by the Psychology, Department of at DigitalCommons@University of Nebraska - Lincoln. It has been accepted for inclusion in Faculty Publications, Department of Psychology by an authorized administrator of DigitalCommons@University of Nebraska - Lincoln. 


\title{
Behavioral and neuropharmacological characterization of nicotine as a conditional stimulus
}

\author{
Jennifer E. Murray and Rick A. Bevins \\ Department of Psychology, University of Nebraska-Lincoln, Lincoln, NE 68588-0308, USA
}

Submitted November 2006; revised January 2007; accepted January 11, 2007; published online February 1, 2007.

\begin{abstract}
In rats, the pharmacological (interoceptive) effects of $0.4 \mathrm{mg} / \mathrm{kg}$ nicotine can serve as a conditional stimulus in a Pavlovian conditioning task. Nicotine administration is paired with intermittent access to a liquid sucrose unconditional stimulus; sucrose is withheld on saline sessions. An increase in sucrose receptacle entries (goal tracking) on nicotine sessions indicates conditioning. Rats were trained on a nicotine dose ((-)-1-Methyl-2-(3-pyridyl)pyrrolidine; $0.1,0.2$, or $0.4 \mathrm{mg}$ base $/ \mathrm{kg}$, s.c.). Generalization was examined using $0.025,0.05,0.1,0.2$, and $0.4 \mathrm{mg} / \mathrm{kg}$ nicotine and saline. Some behavioral effects of nicotine have been attributed to dopamine and glutamate. Accordingly, potential blockade of the nicotine cue via the dopamine system was examined by administering (R)-(+)-7-Chloro-8-hydroxy-3-methyl-1-phenyl-2,3,4,5-tetrahydro-1H-3-benzazepine hydrochloride (SCH-23390; 0.005, 0.01, and $0.03 \mathrm{mg} / \mathrm{kg}$ ), 3-Chloro-5-ethyl-N-[[(2S)-1-ethyl-2-pyrrolidinyl)methyl]-6-hydroxy-2-methoxy-benzamide hydrochloride (eticlopride; $0.01,0.03,0.1$, and $0.3 \mathrm{mg} / \mathrm{kg}$ ), or N-[(1-Butyl-2-pyrrolidinyl)methyl]-4-cyano-1-methoxy-2-naphthalenecarboxamide (nafadotride; $0.03,0.1,0.3,1$, and $3 \mathrm{mg} / \mathrm{kg}$ ) before nicotine. 2-Methyl-6-(phenylethynyl)pyridine hydrochloride (MPEP; $0.3,1$, and 3 $\mathrm{mg} / \mathrm{kg}$ ) and (5S,10R)-(+)-5-Methyl-10,11-dihydro-5H-dibenzo[a,d]cyclohepten-5,10-imine maleate (MK-801; 0.01, 0.03, 0.1, and $0.2 \mathrm{mg} / \mathrm{kg}$; dizocilpine) were used to examine possible glutamatergic components. Substitution tests were conducted with MPEP and nafadotride. Differential conditioned responding was acquired in the 3 groups. Conditioned responding generally decreased as the nicotine test dose moved away from the training dose; responding increased when $0.4 \mathrm{mg} / \mathrm{kg}$ trained rats were tested with 0.2 $\mathrm{mg} / \mathrm{kg}$. SCH-23390, eticlopride, nafadotride, and MPEP decreased conditioned responding on nicotine at doses that also decreased chamber activity. In contrast, MK-801 decreased goal tracking on nicotine without decreasing chamber activity, indicating a role for $\mathrm{N}$-methyl-D-aspartate receptors in expression of nicotine-evoked conditioned responding.
\end{abstract}

Keywords: Classical conditioning, CS, US, Drug discrimination, Nicotinic acetylcholine receptor, NMDA receptor, Interoceptive cue

\section{Introduction}

Within a Pavlovian drug conditioning framework, research on nicotine has focused on its unconditioned stimulus properties. For example, repeated pairings of a conditional stimulus such as a chamber or flavor with a nicotine unconditioned stimulus can produce a place preference (Fudala et al., 1985, Shoaib et al., 1994a and Shoaib et al., 1994b), taste aversion (Iwamoto and Williamson, 1984 and Kumar et al., 1983), or conditioned hyperactivity (Bevins and Palmatier, 2003, Bevins et al., 2001, Bevins et al., 2005, Shoaib et al., 1994a, Shoaib et al., 1994b and Walter and Kuschinsky, 1989) in rats. More recently, sys- temic nicotine has been found to serve as a positive drug feature (occasion setter) indicating when a discrete light conditional stimulus will be followed by brief access to liquid sucrose (Bevins and Palmatier, 2004, Palmatier et al., 2004 and Palmatier et al., 2005). Nicotine can also cue when a discrete light conditional stimulus will not be followed by sucrose, thereby serving as a negative drug feature (Bevins et al., 2006).

Nicotine has also recently been shown to serve as an interoceptive contextual conditional stimulus for access to sucrose in rats (Besheer et al., 2004 and Wilkinson et al., 2006b). Briefly, in that research, a subcutaneous (s.c.) injection of $0.4 \mathrm{mg}$ base/ $\mathrm{kg}$ nicotine or saline was given $5 \mathrm{~min}$ before placement in a 
conditioning chamber. On nicotine sessions, liquid sucrose was delivered intermittently. On intermixed saline sessions, sucrose was not available. Using head entries into the sucrose receptacle before the first sucrose delivery as a measure of conditioning (i.e., goal tracking; Boakes, 1977 and Farwell and Ayres, 1979), nicotine readily served as a conditional stimulus as evidenced by increased dipper entries on nicotine compared to saline sessions. Importantly, when a group of rats had access to sucrose on both nicotine and saline sessions, differential conditioned responding did not develop (Wilkinson et al., 2006b).

The current study sought to extend that research by assessing whether 0.2 and $0.1 \mathrm{mg} / \mathrm{kg}$ nicotine can also serve as a conditional stimulus in the same paradigm. To date, initial acquisition of the discrimination has used $0.4 \mathrm{mg} / \mathrm{kg}$ nicotine (Besheer et al., 2004 and Wilkinson et al., 2006b). Bevins and Palmatier (2004) reported that 0.2 and $0.1 \mathrm{mg} / \mathrm{kg}$ nicotine served as a conditional stimulus for a sucrose unconditioned stimulus when the doses were faded from $0.4 \mathrm{mg} / \mathrm{kg}$. In that research, rats were trained as previously described with $0.4 \mathrm{mg} / \mathrm{kg}$ nicotine. After acquisition, the nicotine conditional stimulus was shifted to 0.2 $\mathrm{mg} / \mathrm{kg}$. Once conditioned responding stabilized, the $0.2 \mathrm{mg} / \mathrm{kg}$ conditional stimulus was again shifted and subsequently stabilized at $0.1 \mathrm{mg} / \mathrm{kg}$. Because the lower nicotine doses came to control nicotine-evoked conditioned responding and because each of these nicotine doses are effective discriminative cues in the operant conditioning literature without use of a fading procedure (Chance et al., 1977, Desai et al., 2003, Gasior et al., 1999, Morrison and Stephenson, 1969, Pratt et al., 1983 and Stolerman et al., 1997), we expected 0.2 and $0.1 \mathrm{mg} / \mathrm{kg}$ to function as conditional stimuli even when trained as the initial conditional stimuli for sucrose.

Another purpose of the present study was to begin to elucidate the neuropharmacological mechanisms of the nicotine conditional stimulus. Nicotine administration to rats increases dopamine release in the nucleus accumbens (Di Chiara and Imperato, 1988, Imperato et al., 1986, Pidoplichko et al., 2004, Pontieri et al., 1996 and Toth et al., 1992). This dopamine release is attributed to presynaptic activation of nicotinic acetylcholine receptors on ventral tegmental area afferents, as well as direct postsynaptic nicotinic acetylcholine receptor activation on dopaminergic neurons projecting to the nucleus accumbens (Corrigall et al., 1994 and Nisell et al., 1994). Links have been made between dopamine receptor function and a variety of nicotine effects. For example, $\mathrm{SCH}-23390$ is a dopamine $\mathrm{D}_{1}$ receptor antagonist (Andersen and Grønvald, 1986, Hyttel and Arnt, 1987 and Iorio et al., 1983) that blocks nicotine-induced increases of dopamine in the nucleus accumbens (Sziráki et al., 1998). SCH23390 has also been found to block the expression of nicotineconditioned hyperactivity without affecting activity in controls (Bevins et al., 2001) and to reverse nicotine-induced lowering of brain reward thresholds (Harrison et al., 2002). When eticlopride, a dopamine $\mathrm{D}_{2} / \mathrm{D}_{3}$ receptor antagonist (Hall et al., 1985, Köhler et al., 1986 and Tang et al., 1994), is infused into the ventral tegmental area, nicotine-induced increases in dopamine in the nucleus accumbens are partially inhibited (Sziráki et al., 2002). Dopamine $D_{3}$ receptor antagonists have been shown to block expression of nicotine-conditioned place preference (Le Foll et al., 2005) and nicotine-conditioned hyperactivity (Le Foll et al., 2003). Although the effects of the dopamine $\mathrm{D}_{3}$ receptor antagonist nafadotride have not been explicitly studied with nicotine, its specificity in vivo makes it a useful tool for studying potential dopamine $\mathrm{D}_{3}$-mediated behaviors (Audinot et al., 1998 and Levant and Vansell, 1997). In brief, given the clear effects of nicotine on dopamine, we examined the potential role of dopamine $\mathrm{D}_{1}, \mathrm{D}_{2}$, and $\mathrm{D}_{3}$ receptors in mediating nicotine's ability to function as a conditional stimulus.

Nicotine administration also modulates glutamate function. Glutamatergic afferents to the ventral tegmental area from the prefrontal cortex contain presynaptic nicotinic acetylcholine receptors that, when activated, increase neurotransmitter release (McGehee et al., 1995 and Schilström et al., 2000). Administration of nicotine increases glutamate levels in the striatum and nucleus accumbens relative to saline controls (Reid et al., 2000 and Toth et al., 1992). Moderate doses of MPEP, a metabotropic glutamate receptor type 5 antagonist (Gasparini et al., 1999), have been shown to decrease nicotine self-administration in rats without affecting responding for food (Kenny et al., 2003 and Paterson et al., 2003). MPEP also decreased drug-seeking behavior during nicotine- and cue-induced reinstatement of nicotine self-administration without affecting food-seeking reinstatement (Bespalov et al., 2005 and Tessari et al., 2004) showing a role for metabotropic glutamate receptor type 5 activation in the rewarding effects of nicotine. Additionally, in an operant drug discrimination task using $0.6 \mathrm{mg} / \mathrm{kg}$ nicotine as a discriminative stimulus for food reinforcement, MPEP partially blocked differential lever pressing controlled by nicotine without affecting response rate (Zakharova et al., 2005). Accordingly, we tested MPEP to examine the role of metabotropic glutamate receptor type 5 activation in the cueing effects of nicotine.

Postsynaptic $N$-methyl-D-aspartate receptors are only activated when glutamate binds to its site on the receptor and the cell membrane has sufficiently depolarized to remove $\mathrm{Mg}^{2+}$ from blocking the receptor channel, and therefore serve to combine chemical and electrical messaging (Ascher and Nowak, 1988 and Kiss et al., 1994). Glutamate release via nicotinic acetylcholine receptor stimulation ultimately activates $N$-methyl-Daspartate receptors, increasing ventral tegmental area dopaminergic burst firing into the nucleus accumbens (Schilström et al., 2003 and Schilström et al., 2004). Blockade of $N$-methylD-aspartate receptors using MK-801, a non-competitive channel blocker (Amador and Dani, 1991, Halliwell et al., 1989, Huettner and Bean, 1988 and Wong et al., 1986) inhibited nicotine-induced dopamine release in the nucleus accumbens (Sziráki et al., 1998). MK-801 also attenuated development and expression of nicotine-induced behavioral sensitization and the development of tolerance to the locomotor depressant effects of nicotine (Shim et al., 2002, Shoaib et al., 1994a, Shoaib et al., 1994b, Shoaib et al., 1997 and Shoaib and Stolerman, 1992). Due to the apparent role of $N$-methyl-D-aspartate receptors in modulation of behavioral effects of nicotine, we used MK-801 to determine if $N$-methyl-D-aspartate receptor activation is involved in nicotine's ability to serve as a conditional stimulus. 


\section{Materials and methods}

\subsection{Subjects}

Twenty-seven male Sprague-Dawley rats $(302 \pm 17 \mathrm{~g}$ at start of study) were obtained from Harlan (Indianapolis, IN, USA). Rats had previously been used in a brief drug-free study assessing whether exposure to an alternate environment proactively interfered with familiarization of a testing environment as indexed by novel object interaction (Wilkinson et al., 2006a). Rats were housed individually in clear $48.3 \times 26.7 \times 20.3 \mathrm{~cm}$ $(1 \times \mathrm{w} \times \mathrm{h})$ polycarbonate tubs lined with aspen shavings. Water was continuously available in the home cage. Rats received food (Harlan Teklad Rodent Diet) after completion of daily sessions and the quantity was restricted as to maintain rats at $85 \%$ of free-feeding body weights. Approximately every 4 weeks the $85 \%$ target weight was increased by $2 \mathrm{~g}$. The colony was temperature and humidity controlled. All sessions were conducted during the light portion of a $12 \mathrm{~h}$ light:dark cycle. Protocols were approved by the University of Nebraska-Lincoln Animal Care and Use Committee and followed the 'Guide for the Care and Use of Laboratory Animals' (National Research Council, 1996).

\subsection{Apparatus}

Eight conditioning chambers (ENV-008CT; Med Associates, Inc., St. Albans, VT, USA) measuring $30.5 \times 24.1 \times 21.0 \mathrm{~cm}(1$ $\times \mathrm{w} \times \mathrm{h}$ ) were used in this study. Sidewalls were aluminum; the ceiling and front and back walls were clear polycarbonate. Each chamber was equipped with a recessed receptacle $(5.2 \times 5.2 \times$ $3.8 \mathrm{~cm} ; 1 \times \mathrm{w} \times \mathrm{d}$ ) on one sidewall. A dipper arm raised a 0.1 $\mathrm{ml}$ cup of $26 \%$ sucrose solution (w/v) into the receptacle. An infrared emitter/detector unit, $1.2 \mathrm{~cm}$ into the receptacle and 3 $\mathrm{cm}$ from the chamber floor, monitored head entries into the dipper. A second infrared emitter/detector unit was added to each chamber during the study to provide a measure of general activity. This unit bisected the chamber $14.5 \mathrm{~cm}$ from the sidewall containing the receptacle and was positioned $4 \mathrm{~cm}$ above the rod floor. Each chamber was enclosed in a light- and soundattenuating cubicle fitted with a fan to provide airflow and mask noise. A personal computer with Med Associates interface and software (Med-PC for Windows, version IV) controlled sucrose deliveries and recorded dipper entries and chamber activity.

\subsection{Drugs}

(-)-1-Methyl-2-(3-pyridyl)pyrrolidine (nicotine), (R)-(+)7-Chloro-8-hydroxy-3-methyl-1-phenyl-2,3,4,5-tetrahydro1H-3-benzazepine hydrochloride (SCH-23390), and 3-Chloro-5-ethyl-N-[[(2S)-1-ethyl-2-pyrrolidinyl)methyl]-6-hydroxy-2-methoxy-benzamide hydrochloride (eticlopride) were purchased from Sigma (St. Louis, MO, USA). 2-Methyl-6(phenylethynyl)pyridine hydrochloride (MPEP), (5S,10R)(+)-5-Methyl-10,11-dihydro-5H-dibenzo[a,d]cyclohepten5,10-imine maleate (MK-801; dizocilpine), and N-[(1-Butyl-2pyrrolidinyl)methyl]-4-cyano-1-methoxy-2-naphthalenecarbox- amide (nafadotride) were purchased from Tocris Cookson, Inc. (Ellisville, MO, USA). Nafadotride was dissolved at $100 \mathrm{mM}$ in 1 eq. $\mathrm{HCl}$. Distilled water was then added to obtain desired concentrations. All other drugs were mixed in $0.9 \%$ saline solution. Nicotine was adjusted to a $\mathrm{pH}$ of $7.0 \pm 0.2$ using a dilute $\mathrm{NaOH}$ solution and injected s.c. $5 \mathrm{~min}$ before placement in the chamber. Remaining drugs were injected intraperitoneally (i.p.) $30 \mathrm{~min}$ before testing. All solutions were injected at $1 \mathrm{ml} / \mathrm{kg}$. Nicotine doses are reported in the base form; remaining doses are salt form.

\subsection{Acquisition}

Rats were randomly assigned to a training dose ( $n=9 /$ dose $)$ of nicotine $(0.1,0.2$, or $0.4 \mathrm{mg} / \mathrm{kg})$ and handled for at least 3 min per day for 3 days. Rats were then given an injection of their training dose of nicotine for the next 3 days in the home cage in order to attenuate the initial locomotor suppressant effects of nicotine (Besheer et al., 2004 and Bevins et al., 2001). Daily training sessions began the day following the last nicotine injection. Rats received either nicotine or saline s.c. $5 \mathrm{~min}$ before placement in the chambers for $20 \mathrm{~min}$. During nicotine sessions, there were 36 deliveries of $4-s$ access to sucrose. In order to discourage timing of sucrose deliveries, 4 different programs were created. The average time before the first sucrose delivery across programs was $137 \mathrm{~s}$ with a range of 124-152 s. No sucrose was delivered during saline sessions. Session types and programs were randomly assigned with the restriction that no more than 2 nicotine or 2 saline sessions occurred in a row. Training continued for 22 nicotine and 22 saline sessions.

\subsection{Testing}

Following acquisition of the discrimination, rats entered the testing phase. On the first 4 consecutive days of a 5-day cycle, rats received 2 nicotine and 2 saline training sessions as described earlier. If a rat met the discrimination criterion (see later), on day 5 a 4-min test session occurred in place of a training session; no sucrose was delivered in testing. If the criterion was not met, the rat was not tested and remained in its home cage.

\subsubsection{Nicotine generalization}

On test days, each rat received a dose of nicotine (see Table 1) or saline injected s.c. $5 \mathrm{~min}$ before placement in the chamber for the 4-min test sessions. Rats received the test solutions in a random order. Upon completion of the first order, each dose was given again in a different random order. Due to the consistent motor ataxia produced by $0.6 \mathrm{mg} / \mathrm{kg}$ nicotine, that dose was removed from the testing sequence after a few rats had tested and was not included in any analysis or figure.

\subsubsection{Antagonism and substitution}

Following completion of nicotine generalization, testing cycles continued as previously described. Photobeams bisecting the chamber were added at this time to provide a measure of general activity. On antagonism test sessions, the antagonist 
Table 1

Order of antagonism and substitution testing phases

\begin{tabular}{llll}
\hline Type & Drug(s) & Doses $(\mathrm{mg} / \mathrm{kg})$ & Nicotine \\
\hline Generalization & Nicotine & $0.025,0.05,0.1,0.2,0.4$, saline & - \\
Antagonism & MPEP & $0.3,1,3$ saline & Yes \\
Antagonism & SCH-23390 & $0.005,0.01,0.03$ saline & Yes \\
& Eticlopride & $0.01,0.03,0.1,0.3$ & \\
Substitution & MPEP & $0.3,1,3$ saline & No \\
Antagonism & Nafadotride & $0.03,0.1,0.3,1,3$ saline & Yes \\
& MK-801 & $0.01,0.03,0.1$ & \\
Substitution & Nafadotride & $0.03,0.1,0.3,1,3$ saline & No \\
Antagonism & MK-801 & $0.2^{\mathrm{a}}$ & Yes \\
\hline
\end{tabular}

${ }^{\text {a }} 0.2 \mathrm{mg} / \mathrm{kg}$ MK- 801 was tested and analyzed separately as it was added after nafadotride substitution (see Results).

was administered i.p. 30 min before placement in the chamber $25 \mathrm{~min}$ before injection of the nicotine training dose. Substitution sessions were similar except nicotine was not administered before the test session. Table 1 shows the progression of testing. Within each phase, the test doses and saline were randomly intermixed. Rats completed all ligands and doses in a phase before beginning the next phase.

\subsection{Dependent measures}

The dependent measure for acquisition was the rate of dipper entries per $\mathrm{s}$ before the first sucrose delivery. In order to allow comparable measurement between nicotine (i.e., sucrose) and saline sessions (i.e., no sucrose), the program types were matched for timing of the intervals from which the dependent measure (i.e., dipper entry rate) was taken. A difference score was then calculated by taking the dipper entry rate before the first sucrose delivery on nicotine sessions minus the dipper entry rate on corresponding saline sessions. A difference score of 0 indicates no discrimination. A positive difference score indicates higher rate of dipper entries on nicotine than saline sessions. The dependent measure for test sessions was the dipper entry rate in the first $2 \mathrm{~min}$ of the test (cf. Besheer et al., 2004). The first 2 min was used to approximate the average time before the first sucrose delivery in nicotine training sessions. In antagonism and substitution testing, a general activity rate (beam breaks per $\mathrm{s}$ in the first $2 \mathrm{~min}$ of the test) was also analyzed. The testing criterion was that the dipper entry rate on each nicotine session was a minimum of 0.01 entries per $\mathrm{s}$ higher than each saline session across the 4 training days of a testing cycle.

\subsection{Data analysis}

Difference scores for acquisition were examined using a 2way analysis of variance (ANOVA) comparing the nicotine training groups $(0.1,0.2$, or $0.4 \mathrm{mg} / \mathrm{kg}$ ) across sessions. To more thoroughly examine the discrimination patterns, 2-way
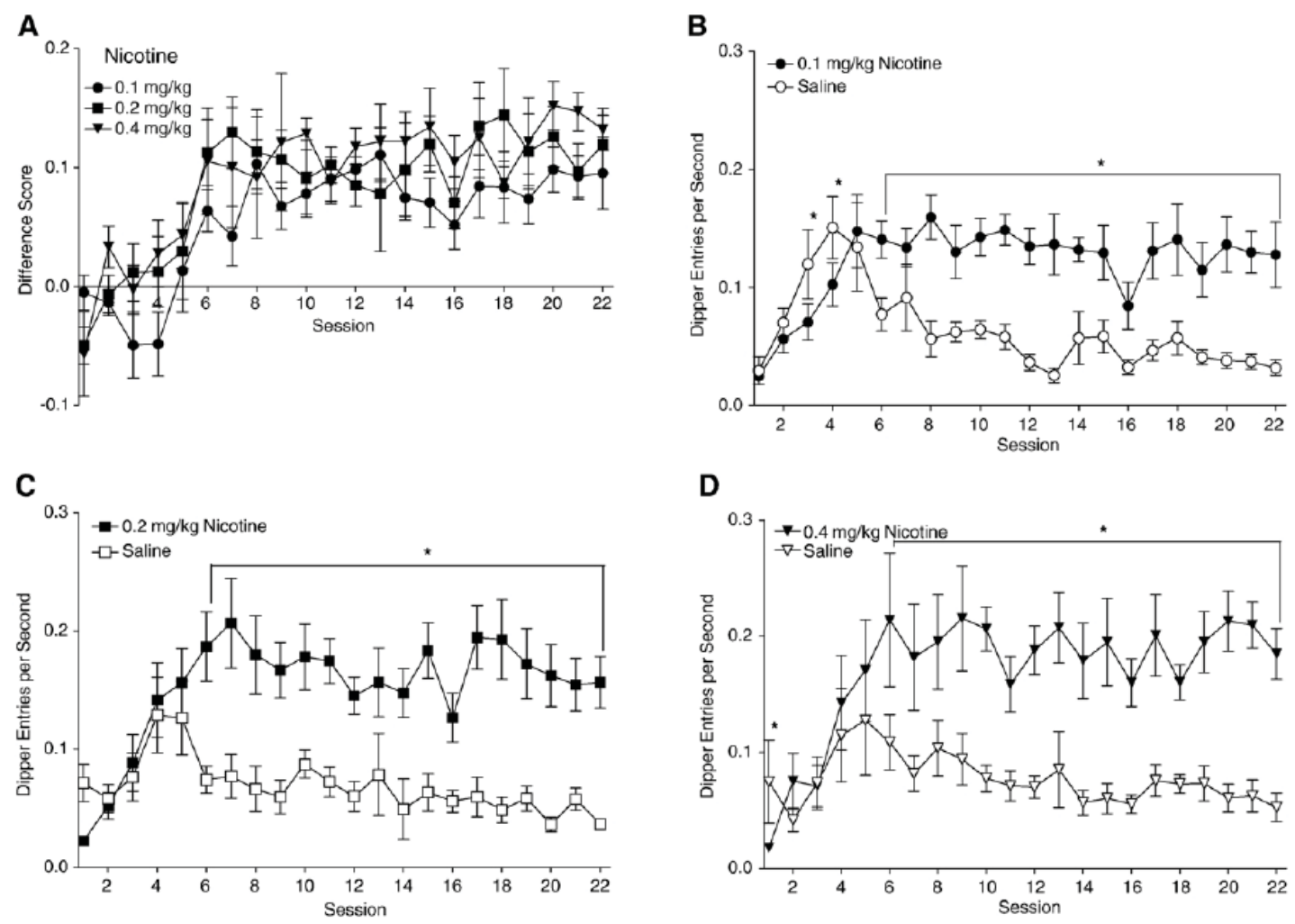

Fig. 1. Panel A shows the mean difference scores (nicotine dipper entry rate minus saline session dipper entry rate; \pm 1 S.E.M.) of discrimination training for each group. Panels B-D show mean dipper entries per s ( \pm 1 S.E.M.) on nicotine and saline sessions during discrimination training for each group. The number of rats per group for acquisition was 9,9 , and 9 for the $0.1,0.2$, and $0.4 \mathrm{mg} / \mathrm{kg}$ groups, respectively. denotes significant difference between dipper entry rates on corresponding nicotine and saline sessions, $P<0.05$. 
ANOVAs were conducted for each training group to compare dipper entry rates on nicotine versus saline across sessions. For nicotine generalization, antagonism, and substitution, 2-way ANOVAs were used to compare dose of ligand across nicotine groups for dipper entry and activity rates. ANOVAs were followed by pair-wise comparisons using Fisher's least significant difference (LSD) tests that control for Type I error rate. Median effective doses $\left(\mathrm{ED}_{50} \mathrm{~s}\right)$ were calculated on the linear portions of nicotine generalization curves and antagonists resulting in full blockade of conditioned responding. Statistical significance was declared using a 2-tailed rejection region of 0.05 for all tests.

\section{Results}

\subsection{Acquisition}

Fig. 1A shows the difference scores for each nicotine dose. There was a main effect of Session $[F(21,483)=10.21, P<$ $0.001]$, but no main effect of Group $[F(2,23)=2.49, P>0.05]$ or Group $\times$ Session interaction $[F<1]$. This pattern indicates that the discrimination was acquired at the same pace and to a similar degree regardless of nicotine dose. For acquisition of each nicotine dose (see Fig. 1B-D), there were significant main effects of Type (nicotine versus saline) $\left[F \mathrm{~S} \geq 40.71, P_{\mathrm{S}}<0.001\right]$, Session $\left[F_{\mathrm{S}} \geq 2.22, P \mathrm{~S}<0.01\right]$, and Type $\times$ Session interactions $[F \mathrm{~S} \geq 3.36, P \mathrm{~S}<0.001$, mean square errors $(\mathrm{MSE}) \leq 0.003]$. For the $0.1 \mathrm{mg} / \mathrm{kg}$ group, dipper entry rates were lower on nicotine than saline for sessions 3 and 4 , and higher for sessions 6-22 [LSD mimimum mean difference $(\mathrm{mmd})=0.041]$. For the $0.2 \mathrm{mg} /$ $\mathrm{kg}$ group, dipper entry rates were higher on nicotine than saline for sessions 6-22 [LSD $\left.{ }_{\text {mmd }}=0.051\right]$. For the $0.4 \mathrm{mg} / \mathrm{kg}$ group, there were lower dipper entry rates on nicotine than saline for session 1, and higher for sessions 6-22 $\left[\mathrm{LSD}_{\mathrm{mmd}}=0.054\right] . \leq$

\subsection{Testing}

\subsubsection{Nicotine generalization}

Fig. 2 shows the generalization curves for each training dose of nicotine. The mean of the 2 test scores for each rat was used for analyses and graphing. A rat trained with $0.4 \mathrm{mg} / \mathrm{kg}$ nicotine was removed during this phase for failure to maintain the

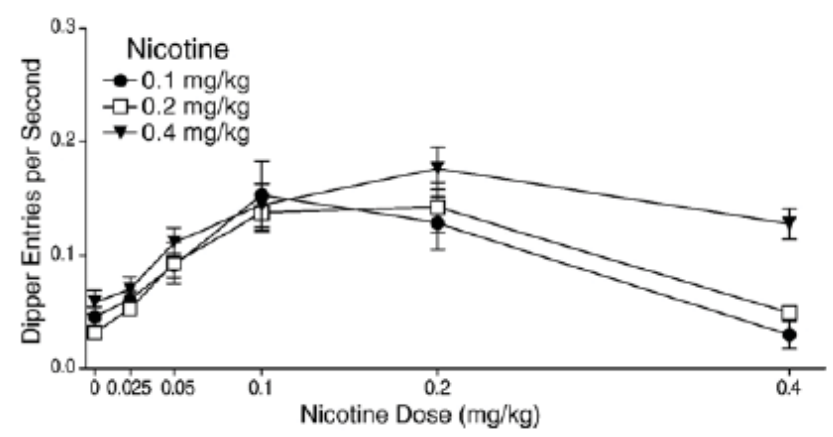

Fig. 2. This figure shows the mean dipper entry rates ( \pm 1 S.E.M.) of nicotine generalization for each group. The number of rats per group for generalization was 9,9 , and 8 for the $0.1,0.2$, and $0.4 \mathrm{mg} / \mathrm{kg}$ groups, respectively. Significant differences and $\mathrm{ED}_{50} \mathrm{~s}$ are reported in the text.
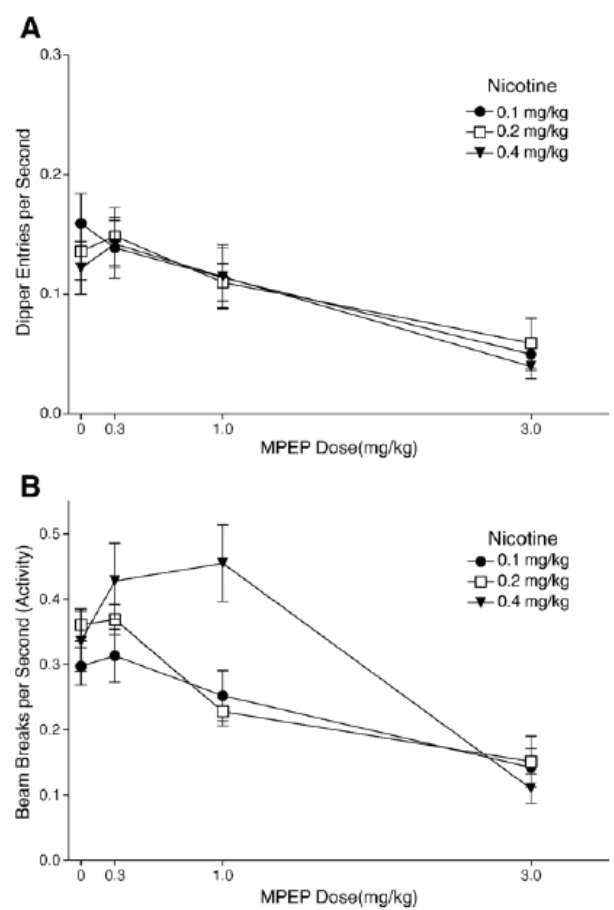

Fig. 3. Panel A shows the mean dipper entry rates ( \pm 1 S.E.M.) of MPEP antagonism for each nicotine training group. Panel B shows the mean beam break (activity) rates ( \pm 1 S.E.M.) of MPEP antagonism for each nicotine training group. The number of rats per group for MPEP antagonism was 9,9 , and 8 for the $0.1,0.2$, and $0.4 \mathrm{mg} / \mathrm{kg}$ groups, respectively. For both panels, significant differences, $\mathrm{ED}_{50} \mathrm{~S}$, and baseline means are reported in the text.

discrimination. Although there was no main effect of Group $[F(2,23)=294.52, P=0.062]$, there was a main effect of Nicotine $[F(5,115)=32.81, P<0.001]$ and a significant Group $\times$ Nicotine interaction $[F(10,115)=2.11, P=0.029, \mathrm{MSE}=$ $0.002]$. For the $0.1 \mathrm{mg} / \mathrm{kg}$ group, dipper entry rates for 0.05 , 0.1 , and $0.2 \mathrm{mg} / \mathrm{kg}$ were higher than saline $\left[\mathrm{LSD}_{\mathrm{mmd}}=0.042\right]$. Further, dipper entry rates on saline, $0.025,0.05$, and $0.4 \mathrm{mg} /$ $\mathrm{kg}$ were lower than that of the $0.1 \mathrm{mg} / \mathrm{kg}$ training dose. For the $0.2 \mathrm{mg} / \mathrm{kg}$ group, dipper entry rates for $0.05,0.1$, and $0.2 \mathrm{mg} /$ $\mathrm{kg}$ were higher than saline; rates for saline, $0.025,0.05$, and 0.4 $\mathrm{mg} / \mathrm{kg}$ were lower than the $0.2 \mathrm{mg} / \mathrm{kg}$ training dose. For the 0.4 $\mathrm{mg} / \mathrm{kg}$ group, dipper entry rates were higher for $0.05,0.1,0.2$, and $0.4 \mathrm{mg} / \mathrm{kg}$ than saline; saline and $0.025 \mathrm{mg} / \mathrm{kg}$ were lower than the training dose. Notably, in rats trained on $0.4 \mathrm{mg} / \mathrm{kg}$, goal tracking increased on $0.2 \mathrm{mg} / \mathrm{kg}$ relative to the training dose. $\mathrm{ED}_{50} \mathrm{~s}$ for the $0.1,0.2$, and $0.4 \mathrm{mg} / \mathrm{kg}$ groups were 0.054 , 0.049 , and $0.050 \mathrm{mg} / \mathrm{kg}$, respectively.

\subsubsection{MPEP antagonism}

Fig. 3A shows the effects of MPEP on dipper entry rates for $0.1,0.2$, and $0.4 \mathrm{mg} / \mathrm{kg}$ nicotine groups. The ANOVA revealed a main effect of Drug $[F(3,69)=26.97, P<0.001]$, but no main effect of Group or Drug $\times$ Group interaction $[F \mathrm{~s}<1$, MSE $=0.002]$, indicating that MPEP comparably decreased conditioned responding to nicotine regardless of training dose. For the $0.1 \mathrm{mg} / \mathrm{kg}$ nicotine group, dipper entry rates were low- 

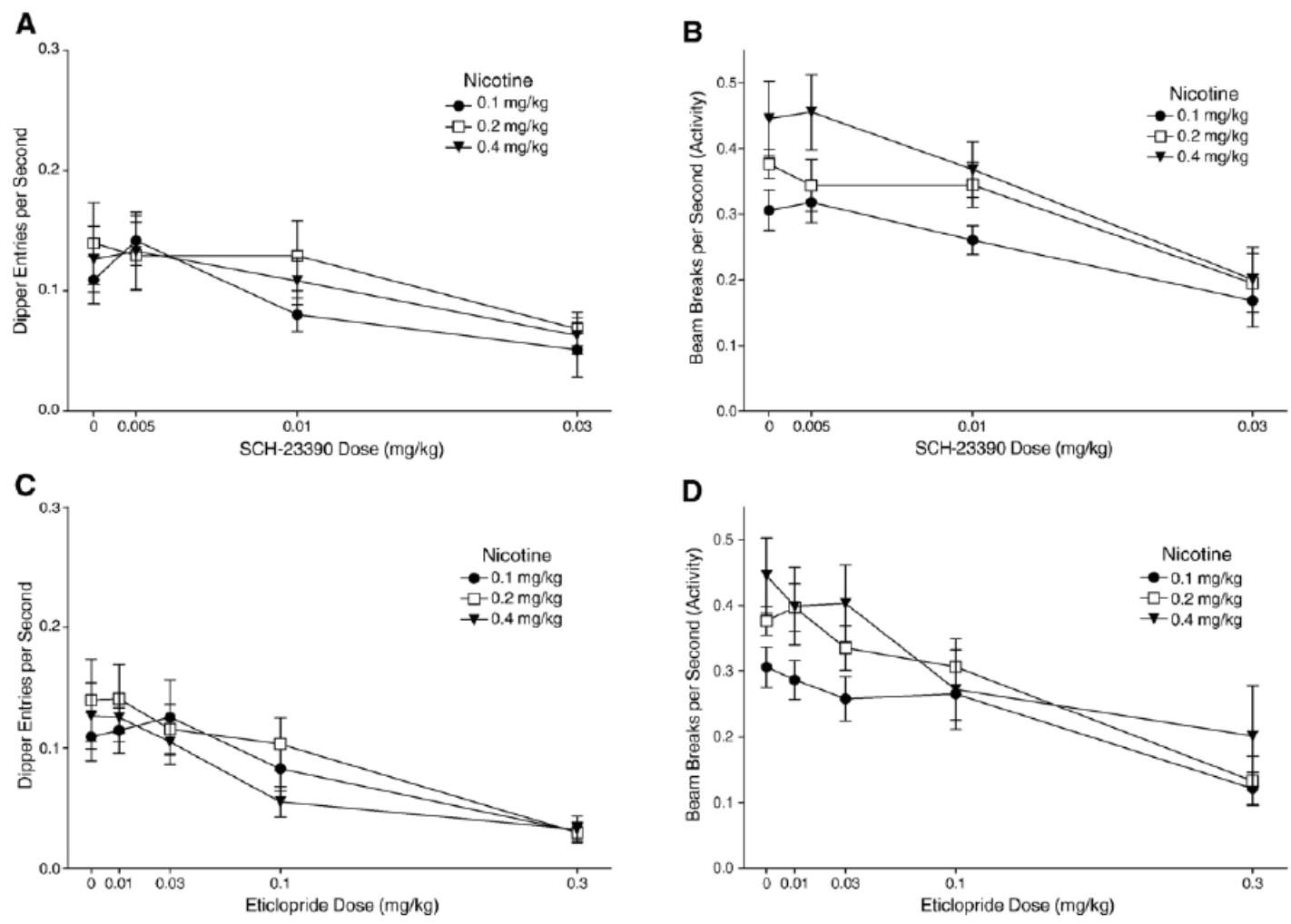

Fig. 4. Panel A shows the mean dipper entry rates ( \pm 1 S.E.M.) of SCH-23390 antagonism for each nicotine training group. Panel B shows the mean beam break (activity) rates $( \pm 1$ S.E.M.) of SCH-23390 antagonism for each nicotine training group. Panel C shows the mean dipper entry rates ( \pm 1 S.E.M.) of eticlopride antagonism for each nicotine training group. Panel D shows the mean beam break (activity) rates ( \pm 1 S.E.M.) of eticlopride antagonism for each nicotine training group. The number of rats was 9 , 9 , and 8 for the $0.1,0.2$, and $0.4 \mathrm{mg} / \mathrm{kg}$ groups, respectively. For all panels, significant differences, $\mathrm{ED}_{50} \mathrm{~s}$, and baseline means are reported in the text.

er after 1 and $3 \mathrm{mg} / \mathrm{kg}$ MPEP than with saline pretreatment [LS$\left.\mathrm{D}_{\mathrm{mmd}}=0.042\right]$. For the 0.2 and $0.4 \mathrm{mg} / \mathrm{kg}$ groups, dipper entry rates were lower with $3 \mathrm{mg} / \mathrm{kg}$ MPEP pretreatment than saline. Fisher's LSD tests were also used to compare each group to its saline (no nicotine) baseline [Means $(M \mathrm{~s})=0.032 \pm 0.006$ for $0.1 \mathrm{mg} / \mathrm{kg}, 0.021 \pm 0.004$ for $0.2 \mathrm{mg} / \mathrm{kg}$, and $0.039 \pm 0.010$ for $0.4 \mathrm{mg} / \mathrm{kg}$ nicotine]. These baselines were generated using the last saline session for each rat before testing with $1 \mathrm{mg} / \mathrm{kg}$ MPEP (cf. Besheer et al., 2004). For all 3 training doses, dipper entries after saline, 0.3 , and $1 \mathrm{mg} / \mathrm{kg}$ MPEP pretreatment were higher than respective saline baselines. Only $3 \mathrm{mg} / \mathrm{kg}$ MPEP reduced dipper entry rates to saline levels. $\mathrm{ED}_{50} \mathrm{~s}$ for the $0.1,0.2$, and $0.4 \mathrm{mg} / \mathrm{kg}$ groups were $1.64,1.50$, and $1.64 \mathrm{mg} / \mathrm{kg}$ MPEP, respectively.

Fig. 3B shows the effects of MPEP antagonism on chamber activity for $0.1,0.2$, and $0.4 \mathrm{mg} / \mathrm{kg}$ nicotine. Although there was no main effect of Group $[F(2,23)=2.67, P=0.090]$, there was a main effect of Drug $[F(3,69)=31.90, P<0.001]$ and a significant Drug $\times$ Group interaction $[F(6,69)=4.24, P<0.01$, MSE $=0.009]$. For the $0.1 \mathrm{mg} / \mathrm{kg}$ nicotine group, activity decreased after $3 \mathrm{mg} / \mathrm{kg}$ MPEP pretreatment compared with saline [LS$\left.\mathrm{D}_{\mathrm{mmd}}=0.091\right]$. For the $0.2 \mathrm{mg} / \mathrm{kg}$ nicotine group, activity was lower after 1 and $3 \mathrm{mg} / \mathrm{kg}$ MPEP pretreatment compared with saline. Activity for the $0.4 \mathrm{mg} / \mathrm{kg}$ nicotine group was also lower after $3 \mathrm{mg} / \mathrm{kg}$ MPEP pretreatment compared with saline; how- ever, activity increased after 0.3 and $1 \mathrm{mg} / \mathrm{kg}$ MPEP pretreatment for this group.

\subsubsection{SCH-23390 and eticlopride antagonism}

Fig. 4A shows the mean dipper entry rates for responding on nicotine after administration of SCH-23390. There was a main effect of Drug $[F(3,69)=13.00, P<0.001]$, but no main effect of Group or Drug $\times$ Group interaction $\left[F_{\mathrm{S}}<1, \mathrm{MSE}=0.002\right]$ indicating that $\mathrm{SCH}-23390$ decreased conditioned responding to nicotine regardless of training dose. For each training group, dipper entry rates decreased after $0.03 \mathrm{mg} / \mathrm{kg} \mathrm{SCH}-23390$ pretreatment compared to saline $\left[\mathrm{LSD}_{\mathrm{mmd}}=0.042\right]$. A saline (no nicotine) baseline was generated for $\mathrm{SCH}-23390$ using the mean dipper entry rates on the saline session before the 0.005 $\mathrm{mg} / \mathrm{kg} \mathrm{SCH}-23390$ test session $[M \mathrm{~s}=0.027 \pm 0.005,0.036 \pm$ 0.009 , and $0.036 \pm 0.005$ for $0.1,0.2$, and $0.4 \mathrm{mg} / \mathrm{kg}$ nicotine, respectively]. For all groups, conditioned responding was higher than the baseline with 0.005 and $0.01 \mathrm{mg} / \mathrm{kg} \mathrm{SCH}-23390$ and saline pretreatment. Only $0.03 \mathrm{mg} / \mathrm{kg} \mathrm{SCH}-23390$ lowered conditioned responding to saline levels. $\mathrm{ED}_{50} \mathrm{~s}$ for $0.1,0.2$, and 0.4 $\mathrm{mg} / \mathrm{kg}$ nicotine groups were $0.03,0.02$, and $0.02 \mathrm{mg} / \mathrm{kg} \mathrm{SCH}-$ 23390, respectively. Activity rates with SCH-23390 pretreatment are shown in Fig. 4B. There was a significant main effect of Drug $[F(3,69)=19.97, P<0.001]$ and Group $[F(2,23)$ $=3.69, P=0.041, \mathrm{MSE}=0.025]$, but no significant Drug $\times$ 

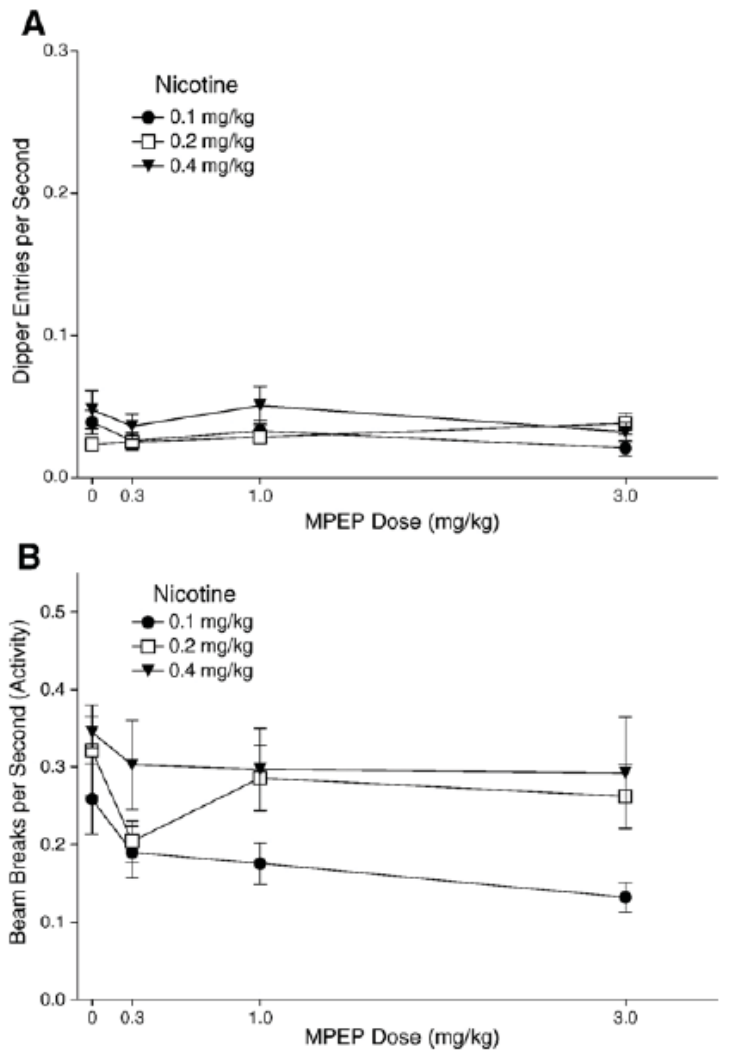

Fig. 5. Panel A shows the mean dipper entry rates ( \pm 1 S.E.M.) of MPEP substitution for each nicotine training group. Panel B shows the mean beam break (activity) rates ( \pm 1 S.E.M.) of MPEP substitution for each nicotine training group. The number of rats for MPEP substitution was 9,9 , and 8 for the $0.1,0.2$, and $0.4 \mathrm{mg} / \mathrm{kg}$ groups, respectively. For both panels, significant differences and baseline means are reported in the text.

Group interaction $[F<1, \mathrm{MSE}=0.010]$. The $0.4 \mathrm{mg} / \mathrm{kg}$ group had higher activity than the $0.1 \mathrm{mg} / \mathrm{kg}$ group $\left[\mathrm{LSD}_{\mathrm{mmd}}=0.055\right]$. For each group, activity was lower with $0.03 \mathrm{mg} / \mathrm{kg} \mathrm{SCH}-23390$ than saline pretreatment $\left[\mathrm{LSD}_{\mathrm{mmd}}=0.096\right]$.

Fig. 4C shows the mean dipper entry rates for each group after eticlopride pretreatment. There was a main effect of Drug $[F(4,92)=17.15, P<0.001]$, but no effect of Group or Drug $\times$ Group interaction $[F \mathrm{~s}<1, \mathrm{MSE}=0.003]$. The 0.1 and $0.2 \mathrm{mg} /$ $\mathrm{kg}$ nicotine had decreased dipper entry rates with $0.3 \mathrm{mg} / \mathrm{kg}$ eticlopride pretreatment compared with saline pretreatment [LSD$\left.{ }_{\mathrm{mmd}}=0.052\right]$. For the $0.4 \mathrm{mg} / \mathrm{kg}$ group, dipper entry rates were lower after 0.1 and $0.3 \mathrm{mg} / \mathrm{kg}$ eticlopride than saline pretreatment. The saline baseline described for SCH-23390 was also used for eticlopride. The 0.1 and $0.2 \mathrm{mg} / \mathrm{kg}$ nicotine-trained groups had higher dipper entries after saline, 0.01, 0.03, and 0.1 $\mathrm{mg} / \mathrm{kg}$ eticlopride pretreatment than baseline saline levels. For the $0.4 \mathrm{mg} / \mathrm{kg}$ group, dipper entries after saline, 0.01 , and 0.03 $\mathrm{mg} / \mathrm{kg}$ eticlopride pretreatment were higher than baseline saline levels. $\mathrm{ED}_{50} \mathrm{~s}$ for $0.1,0.2$, and $0.4 \mathrm{mg} / \mathrm{kg}$ nicotine groups were $0.15,0.17$, and $0.12 \mathrm{mg} / \mathrm{kg}$ eticlopride, respectively. General chamber activity after eticlopride pretreatment is shown in Fig. 4D. There was a main effect of Drug $[F(4,92)=14.95, P$ $<0.001]$ and a main effect of Group $[F(2,23)=3.93, P<0.05]$ but no Drug $\times$ Group interaction $[F<1, \mathrm{MSE}=0.014]$. For the 0.1 and $0.2 \mathrm{mg} / \mathrm{kg}$ groups, activity after $0.3 \mathrm{mg} / \mathrm{kg}$ eticlopride pretreatment was lower than saline $\left[\mathrm{LSD}_{\mathrm{mmd}}=0.113\right]$. For the $0.4 \mathrm{mg} / \mathrm{kg}$ group, activity after 0.1 and $0.3 \mathrm{mg} / \mathrm{kg}$ eticlopride pretreatment was lower than saline.

\subsubsection{MPEP substitution}

The MPEP substitution phase was conducted to further explore the increased activity in the $0.4 \mathrm{mg} / \mathrm{kg}$ group during MPEP antagonism. Fig. 5A shows the effect of MPEP substitution tests on dipper entries. There was no main effect of Drug, Group, or Drug $\times$ Group interaction $\left[F \mathrm{~s} \leq 1.70, P_{\mathrm{S}} \geq 0.188\right]$. Conditioned responding on MPEP did not differ from saline, regardless of training dose of nicotine. General activity for MPEP substitution is shown in Fig. 5B. There were main effects of Drug $[F(3,69)=3.05, P=0.034]$ and Group $[F(2,23)=4.08$, $P=0.030, \mathrm{MSE}=0.031]$, but no significant Drug $\times$ Group interaction $[F<1, \mathrm{MSE}=0.011]$. Follow-up comparisons of the main effect of Group for general activity rates across tests $[M \mathrm{~s}$ $=0.189,0.268$, and 0.309 for $0.1,0.2$, and $0.4 \mathrm{mg} / \mathrm{kg}$ nicotine, respectively] revealed that only the $0.4 \mathrm{mg} / \mathrm{kg}$ group was more active than the $0.1 \mathrm{mg} / \mathrm{kg}$ group, $\left[\mathrm{LSD}_{\mathrm{mmd}}=0.088\right]$. Within individual groups, $3 \mathrm{mg} / \mathrm{kg}$ MPEP decreased activity below that of saline for the $0.1 \mathrm{mg} / \mathrm{kg}$ group, $\left[\mathrm{LSD}_{\mathrm{mmd}}=0.10\right]$. For the 0.2 $\mathrm{mg} / \mathrm{kg}$ group, $0.3 \mathrm{mg} / \mathrm{kg}$ MPEP produced lower general activity than saline. There were no MPEP-induced shifts in activity for the $0.4 \mathrm{mg} / \mathrm{kg}$ group.

\subsubsection{Nafadotride and MK-801 antagonism}

A rat in the $0.1 \mathrm{mg} / \mathrm{kg}$ group and a rat in the $0.4 \mathrm{mg} / \mathrm{kg}$ group were removed due to an inability to continue testing. Fig. 6A shows the mean dipper entry rates for each group after nafadotride pretreatment. There was a main effect of Drug $[F(5,105)=$ 5.01, $P<0.001]$, but no main effect of Group [ $F<1]$ or Drug $\times$ Group interaction $[F(10,105)=1.32, P=0.23, \mathrm{MSE}=0.002]$ indicating that nafadotride decreased conditioned responding on nicotine regardless of training dose. Follow-up analysis of the main effect of Drug showed that overall conditioned responding after $3 \mathrm{mg} / \mathrm{kg}$ nafadotride pretreatment was lower than saline pretreatment $\left[\mathrm{LSD}_{\mathrm{mmd}}=0.025\right]$. However, within individual groups there were no differences between test doses of nafadotride and saline pretreatment $\left[\mathrm{LSD}_{\mathrm{mmd}}=0.048\right]$. A saline (no nicotine) baseline was generated for nafadotride antagonism using the mean dipper entry rates on the saline session before the $0.03 \mathrm{mg} / \mathrm{kg}$ MK-801 test session $[M \mathrm{~s}=0.028 \pm 0.005,0.036 \pm$ 0.004 , and $0.047 \pm 0.010$ for $0.1,0.2$, and $0.4 \mathrm{mg} / \mathrm{kg}$ nicotine, respectively]. For the 0.1 and $0.2 \mathrm{mg} / \mathrm{kg}$ groups, responding on all tests was higher than the saline baseline. For the $0.4 \mathrm{mg} /$ $\mathrm{kg}$ group, dipper entries after $3 \mathrm{mg} / \mathrm{kg}$ nafadotride were similar to the saline baseline. General activity rates after nafadotride pretreatment are shown in Fig. 6B. There was a main effect of Drug $[F(5,105)=5.06, P<0.001]$, but no main effect of Group $[F(2,21)=1.35, P=0.28]$ or Drug $\times$ Group interaction $[F(10,105)=1.65, P=0.103, \mathrm{MSE}=0.007]$. Follow-up analysis for the main effect of Drug indicated that overall activity rates after $3 \mathrm{mg} / \mathrm{kg}$ nafadotride pretreatment was lower than saline $\left[\mathrm{LSD}_{\mathrm{mmd}}=0.048\right]$. For individual groups, activity after 3 
$\mathrm{mg} / \mathrm{kg}$ nafadotride pretreatment was lower than saline pretreatment only for the $0.4 \mathrm{mg} / \mathrm{kg}$ group $\left[\mathrm{LSD}_{\mathrm{mmd}}=0.091\right]$.

Fig. 6C shows the mean dipper entry rates for responding on nicotine after pretreatment with MK-801. There was a main effect of Drug $[F(3,63)=18.63, P<0.001]$, but no main effect of Group or Drug $\times$ Group interaction $[F \mathrm{~S}<1$, MSE $=0.002]$ indicating that MK-801 decreased conditioned responding to nicotine regardless of training dose. For each training group, dipper entry rates after $0.1 \mathrm{mg} / \mathrm{kg} \mathrm{MK}-801$ pretreatment were lower than saline pretreatment $\left[\mathrm{LSD}_{\mathrm{mmd}}=0.044\right]$. The saline baseline described for nafadotride was also used for MK-801. For all nicotine doses, conditioned responding was higher than the saline baseline with pretreatment of 0.01 and $0.03 \mathrm{mg} / \mathrm{kg} \mathrm{MK}$ 801 and saline. Only $0.1 \mathrm{mg} / \mathrm{kg}$ MK-801 lowered conditioned responding to baseline saline levels. $\mathrm{ED}_{50} \mathrm{~s}$ for $0.1,0.2$, and 0.4 $\mathrm{mg} / \mathrm{kg}$ nicotine groups were $0.055,0.052$, and $0.060 \mathrm{mg} / \mathrm{kg} \mathrm{MK}-$ 801 , respectively. Activity after MK-801 pretreatment is shown in Fig. 6D. There was a significant main effect of Drug $[F(3,63)$ $=6.17, P=0.001]$, but no main effect of Group $[F(2,21)=3.19$, $P=0.063]$ or significant Drug $\times$ Group interaction $[F<1, \mathrm{MSE}$ $=0.008]$. Activity was lower on sessions with $0.1 \mathrm{mg} / \mathrm{kg} \mathrm{MK}-$ 801 pretreatment than saline only for the $0.2 \mathrm{mg} / \mathrm{kg}$ group [LS$\left.\mathrm{D}_{\text {mmd }}=0.089\right]$.
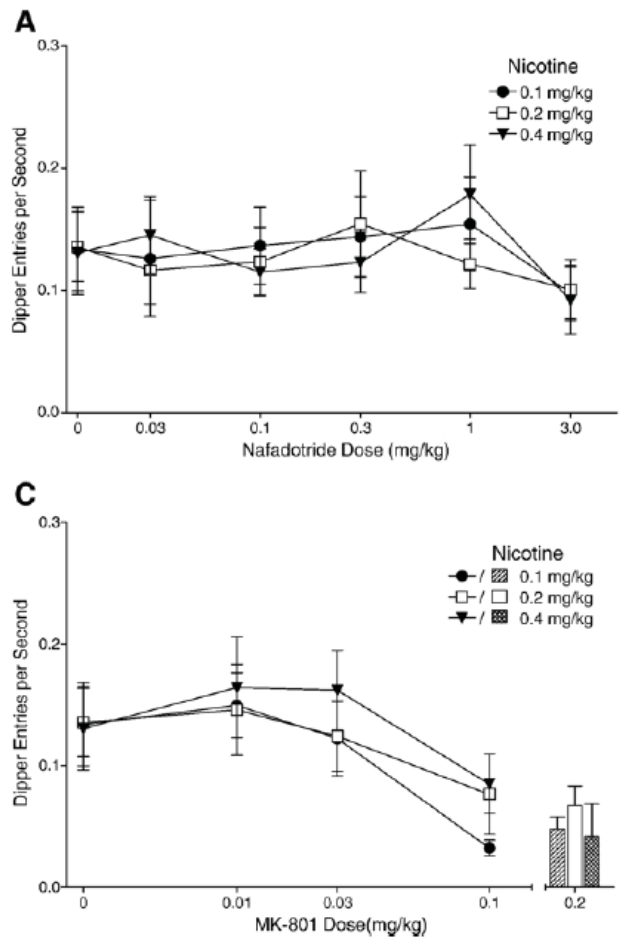

\subsection{6. $\mathrm{MK}-801$ antagonism $(0.2 \mathrm{mg} / \mathrm{kg})$}

This final test was added to extend the observed effect of $0.1 \mathrm{mg} / \mathrm{kg} \mathrm{MK}-801$ to a higher dose. The bars in Fig. $6 \mathrm{C}$ show the dipper entry rates of $0.2 \mathrm{mg} / \mathrm{kg}$ MK-801 antagonism for each nicotine group. A 2-way ANOVA comparing responding on saline and $\mathrm{MK}-801$ pretreatment revealed a main effect of Drug $[F(1,17)=16.64, P=0.001]$, indicating that responding on $0.2 \mathrm{mg} / \mathrm{kg} \mathrm{MK}-801$ pretreatment was lower than on saline pretreatment, but did not reveal a main effect of Group or Drug $\times$ Group interaction $\left[F_{\mathrm{S}}<1, \mathrm{MSE}=\right.$ 0.005 ]. For the 0.1 and $0.4 \mathrm{mg} / \mathrm{kg}$ groups, responding on 0.2 $\mathrm{mg} / \mathrm{kg}$ MK-801 was lower than saline pretreatment LSD $_{\mathrm{mmd}}$ $=0.081]$. There was no difference in dipper entries for the 0.2 $\mathrm{mg} / \mathrm{kg}$ group. Of the $7 \mathrm{rats}$ in the $0.2 \mathrm{mg} / \mathrm{kg}$ nicotine group, a single rat scored more than twice as high as any of the other rats in the condition, causing the lack of difference. Additionally, for all 3 training groups, dipper entry rates on $0.2 \mathrm{mg} / \mathrm{kg}$ MK-801 was the same as the respective saline baselines and responding following saline pretreatment was higher than the saline baselines. Fig. 6D includes the activity rates for the 0.2 $\mathrm{mg} / \mathrm{kg}$ MK-801 antagonism test. There were no main effects of Drug or Group and no Drug $\times$ Group interaction $\left[F_{\mathrm{S}}<1\right.$, $\mathrm{MSE}=0.030]$, indicating that the blockade of conditioned re-
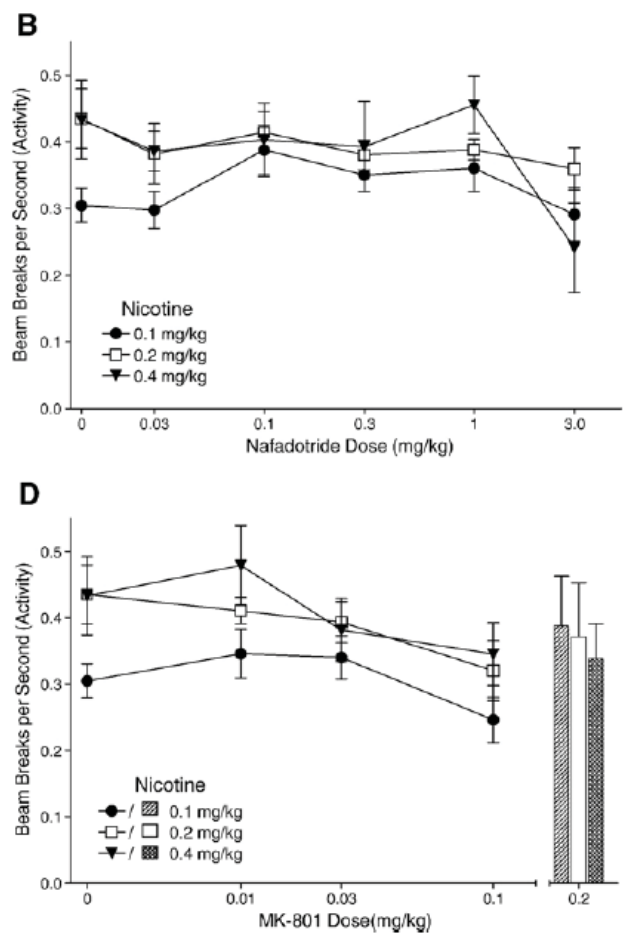

Fig. 6. Panel A shows the mean dipper entry rates ( \pm 1 S.E.M.) of nafadotride antagonism for each nicotine training group. Panel B shows the mean beam break (activity) rates $( \pm 1$ S.E.M.) of nafadotride antagonism for each nicotine training group. Panel C shows the mean dipper entry rates ( \pm or +1 S.E.M.) of MK-801 antagonism for each nicotine training group. Panel D shows the mean beam break (activity) rates $( \pm$ or + 1 S.E.M.) of MK-801 antagonism for each nicotine training group. The number of rats for nafadotride and MK-801 antagonism was 8, 9, and 7 for the $0.1,0.2$, and $0.4 \mathrm{mg} / \mathrm{kg}$ groups, respectively. The $0.2 \mathrm{mg} / \mathrm{kg} \mathrm{MK}-801$ dose is separated from the graphs in panels C and D to represent the procedural separation for testing. The number of rats for the $0.2 \mathrm{mg} / \mathrm{kg} \mathrm{MK}-801$ antagonism test was 7, 7, and 6 for the $0.1,0.2$, and $0.4 \mathrm{mg} /$ $\mathrm{kg}$ groups, respectively. For all panels, significant differences, $\mathrm{ED}_{50} \mathrm{~s}$, and baseline means are reported in the text. 
sponding by $0.2 \mathrm{mg} / \mathrm{kg} \mathrm{MK}-801$ pretreatment was not due to a general decrease in activity.

\subsubsection{Nafadotride substitution}

Tests of nafadotride substitution were conducted because early results from the nafadotride antagonism phase showed a pattern of increased chamber activity that diminished with continued testing. A rat from the $0.1 \mathrm{mg} / \mathrm{kg}$ nicotine group was removed during this portion of the study for failure to eat, and 2 rats from the 0.2 and 1 rat from the $0.4 \mathrm{mg} / \mathrm{kg}$ group were removed due to an inability to continue to test, leaving 7, 7, and 6 rats for groups $0.1,0.2$, and $0.4 \mathrm{mg} / \mathrm{kg}$ nicotine, respectively. Fig. 7A shows dipper entry rates for nafadotride substitution. Although there was no main effect of Drug $[F(5,85)=1.45, P=$ $0.214]$ or Drug $\times$ Group interaction $[F(10,85)=1.41, P=0.188$, MSE $<0.001]$, there was a significant main effect of Group $[F(2,17)=3.79, P=0.044, \mathrm{MSE}=0.004]$. The 0.1 and $0.2 \mathrm{mg} /$ $\mathrm{kg}$ groups had lower overall dipper entry rates than the $0.4 \mathrm{mg} /$ $\mathrm{kg}$ group $\left[\mathrm{LSD}_{\mathrm{mmd}}=0.029 ; \mathrm{Ms}=0.038,0.031\right.$, and 0.066 for the $0.1,0.2$, and $0.4 \mathrm{mg} / \mathrm{kg}$ groups, respectively]. Activity rates for nafadotride substitution are shown in Fig. 7B. There was no effect of Drug $[F<1]$, but there was a significant main effect of Group $[F(2,17)=4.72, P=0.024]$ and a Drug $\times$ Group interaction $[F(10,85)=2.05, P=0.038]$. Overall, there was no difference in activity between the 0.1 and $0.2 \mathrm{mg} / \mathrm{kg}$ group, and the $0.4 \mathrm{mg} / \mathrm{kg}$ group had higher activity rates than 0.1 and $0.2 \mathrm{mg} /$ $\mathrm{kg}$ groups $\left[\mathrm{LSD}_{\mathrm{mmd}}=0.072\right]$. For the 0.1 and $0.4 \mathrm{mg} / \mathrm{kg}$ groups,

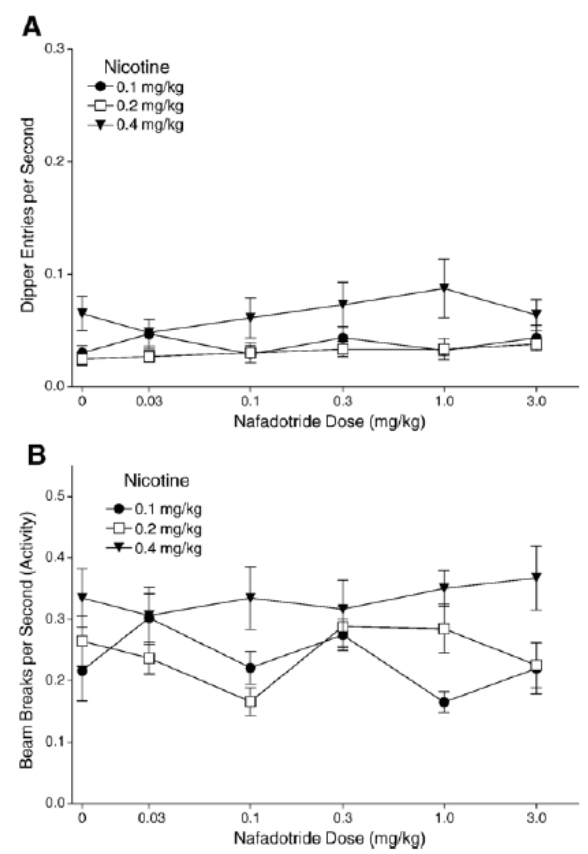

Fig. 7. Panel A shows the mean dipper entry rates ( \pm 1 S.E.M.) of nafadotride substitution for each nicotine training group. Panel B shows the mean beam break (activity) rates ( \pm 1 S.E.M.) of nafadotride substitution for each nicotine training group. The number of rats for nafadotride substitution was 7, 7, and 6 for the $0.1,0.2$, and $0.4 \mathrm{mg} /$ $\mathrm{kg}$ groups, respectively. For both panels, significant differences and baseline means are reported in the text. there were no differences between all tested doses of nafadotride and saline $\left[\mathrm{LSD}_{\mathrm{mmd}}=0.091\right]$. For the $0.2 \mathrm{mg} / \mathrm{kg}$ group, 0.1 $\mathrm{mg} / \mathrm{kg}$ nafadotride decreased activity rates below that of saline.

\section{Discussion}

Consistent with previous research, the $0.4 \mathrm{mg} / \mathrm{kg}$ nicotine group readily acquired conditioned responding for sucrose within 12 training sessions (Besheer et al., 2004, Bevins and Palmatier, 2004 and Wilkinson et al., 2006b). The present study also found that 0.1 and $0.2 \mathrm{mg} / \mathrm{kg}$ nicotine came to evoke robust conditioned responding at a similar rate. Our findings are in contrast to drug discrimination literature using equivalent doses of nicotine as a discriminative stimulus. Each of these 3 training doses has served as a discriminative stimulus for rats in a 2-lever operant drug discrimination task (Chance et al., 1977, Desai et al., 2003, Gasior et al., 1999, Morrison and Stephenson, 1969, Pratt et al., 1983 and Stolerman et al., 1997). In this task, completion of a response requirement on one lever results in reinforcement, whereas responses on the other lever result in no reinforcement (Gasior et al., 2000, Gasior et al., 2002, Morrison and Stephenson, 1969, Pratt et al., 1983, Stolerman, 1989 and Stolerman et al., 1984). On intermixed vehicle sessions, responding on the opposite lever is reinforced. When 0.1 $\mathrm{mg} / \mathrm{kg}$ nicotine is used as the discriminative stimulus (i.e., not faded from $0.4 \mathrm{mg} / \mathrm{kg}$ nicotine), acquisition can take much longer than higher nicotine doses (Chance et al., 1977 and Gasior et al., 1999). For example, rats trained on $0.4 \mathrm{mg} / \mathrm{kg}$ nicotine required 28 to 43 training days before meeting criteria for stable discrimination performance, whereas rats trained on $0.1 \mathrm{mg} /$ $\mathrm{kg}$ nicotine required 38 to 94 training days before meeting the same criteria (Gasior et al., 1999).

The similar acquisition rate in the current study might lead one to conclude that $0.1 \mathrm{mg} / \mathrm{kg}$ nicotine is as salient as the higher nicotine doses (for discussions of effects of conditional stimulus salience on acquisition of Pavlovian conditioning, see Frey and Sears, 1978, Pavlov, 1927, Rescorla, 1988 and Rescorla and Wagner, 1972). A non-salience explanation for the similar acquisition rate of the 3 groups $(0.1,0.2$, and $0.4 \mathrm{mg} / \mathrm{kg}$ ) involves the rich schedule of sucrose deliveries in nicotine sessions. Wilkinson et al. (2006b) used different unconditioned stimulus densities to examine acquisition of conditioned responding with a $0.4 \mathrm{mg} / \mathrm{kg}$ nicotine conditional stimulus. The highest unconditioned stimulus density in that study, 36 intermittent sucrose deliveries over 20-min nicotine sessions, resulted in robust conditioned responding that was acquired within 10 training sessions; acquisition took longer in groups trained with fewer sucrose deliveries per session. Because 0.1 and $0.2 \mathrm{mg} / \mathrm{kg}$ nicotine had not previously been trained as conditional stimuli, the current research used 36 deliveries of sucrose in order to maximize the chances of observing conditioning. The possibility exists that with this many nicotine-sucrose pairings, even a nicotine dose that would otherwise have been a weaker conditional stimulus could come to be a strong conditioned exciter. Our measure of conditioned responding comes from the early por- 
tion of each conditioning session before any sucrose is delivered. If we could measure conditioned responding after every few nicotine-sucrose pairings, differences in acquisition as a function of training dose may have emerged.

In the present study, the 3 nicotine training groups showed decreases in conditioned responding as nicotine test doses were shifted away from the training dose with the exception of the $0.4 \mathrm{mg} / \mathrm{kg}$ trained group when tested with $0.2 \mathrm{mg} / \mathrm{kg}$ (see below). The $\mathrm{ED}_{50} \mathrm{~s}$ were similar across groups $(0.054,0.049$, and $0.050 \mathrm{mg} / \mathrm{kg}$ for $0.1,0.2$, and $0.4 \mathrm{mg} / \mathrm{kg}$ groups, respectively); a finding consistent with the similarities in acquisition rate and magnitude of conditioned responding across training doses. Besheer et al. (2004) found an $\mathrm{ED}_{50}$ of $0.113 \mathrm{mg} / \mathrm{kg}$ for a group trained on $0.4 \mathrm{mg} / \mathrm{kg}$ nicotine. In that study, sucrose was delivered only 8 times on nicotine sessions, whereas in the current research, sucrose was delivered 36 times. This difference suggests that after the greater number of nicotine-sucrose pairings, less nicotine was necessary to prompt conditioned responding. When different nicotine training doses are used in the operant drug discrimination literature, results are mixed as to whether rats trained on low doses of nicotine are more sensitive to the cueing effects of nicotine compared with rats trained on higher doses of nicotine. In several papers, rats trained on $0.1 \mathrm{mg} /$ $\mathrm{kg}$ nicotine tended to have lower $\mathrm{ED}_{50} \mathrm{~s}$ (e.g., $0.026 \mathrm{mg} / \mathrm{kg}$ for Chance et al., 1977; $0.024 \mathrm{mg} / \mathrm{kg}$ for Desai et al., 2003; 0.02 $\mathrm{mg} / \mathrm{kg}$ for Stolerman et al., 1997) than rats trained on $0.4 \mathrm{mg} /$ $\mathrm{kg}$ nicotine (e.g., $0.087 \mathrm{mg} / \mathrm{kg}$ for Chance et al., 1977; $0.09 \mathrm{mg} /$ $\mathrm{kg}$ for Gasior et al., 2002; $0.14 \mathrm{mg} / \mathrm{kg}$ for Pratt et al., 1983). However, this difference is not always observed. Gasior et al. (1999) found that $\mathrm{ED}_{50} \mathrm{~s}$ did not differ between 0.1 and $0.4 \mathrm{mg} /$ $\mathrm{kg}$ groups (0.049 and $0.05 \mathrm{mg} / \mathrm{kg}$, respectively).

Notably, in the present study, rats trained on $0.4 \mathrm{mg} / \mathrm{kg}$ nicotine increased responding when tested with the $0.2 \mathrm{mg} / \mathrm{kg}$ dose. A similar pattern did not occur with the other training doses. This increase in conditioned responding to a lower dose than the $0.4 \mathrm{mg} / \mathrm{kg}$ training dose was a non-significant trend in the Besheer et al. (2004) study in which rats received 8 deliveries of sucrose on nicotine sessions rather than the 36 deliveries used in the present study. Additionally, ongoing research in our laboratory using 36 deliveries of sucrose on nicotine sessions is replicating this effect. Further, a similar trend was also reported by Pratt et al. (1983) in a 2-lever operant drug discrimination task. We believe the increased responding at the lower test dose in our study indicates that expression of conditioned responding is slightly attenuated by an early inhibitory effect of the $0.4 \mathrm{mg} /$ $\mathrm{kg}$ training dose. The exact nature of this inhibitory effect, however, will require further elucidation (see later discussion of activity with MPEP antagonism).

Besheer et al. (2004) found that the $0.4 \mathrm{mg} / \mathrm{kg}$ nicotine conditional stimulus was antagonized by the central and peripheral nicotinic acetylcholine receptor channel-blocking antagonist mecamylamine (Papke et al., 2001), and not by the predominately peripheral nicotinic acetylcholine receptor antagonist hexamethonium (Asghar and Roth, 1971), indicating that the cueing effects of nicotine were centrally mediated. Nicotinic acetylcholine receptors mediate release of both dopamine and glutamate in the mesocorticolimbic region of the brain (Pontieri et al., 1996 and Schilström et al., 2003). Taken together, the results of the current research suggest that there is minimal influence of dopamine $\mathrm{D}_{1}, \mathrm{D}_{2}$, or $\mathrm{D}_{3}$ receptors in the nicotine conditional stimulus. The dopamine $\mathrm{D}_{1}$ and $\mathrm{D}_{2 / 3}$ receptor antagonists, SCH-23390 and eticlopride, respectively, decreased conditioned responding regardless of nicotine training dose. This decrease in conditioned responding, however, coincided with a decrease in general chamber activity, indicating non-specific effects of the antagonists. Although this data pattern precludes us from concluding that dopamine $\mathrm{D}_{1}$ or $\mathrm{D}_{2 / 3}$ receptors are involved in the conditional stimulus effects of nicotine in the present study, it does not eliminate the possibility that other available antagonists for these receptors could block conditioned responding without affecting activity. Albeit less pronounced, there was a similar decrease in activity and conditioned responding for dopamine $\mathrm{D}_{3}$ receptor antagonism with nafadotride in the $0.4 \mathrm{mg} / \mathrm{kg}$ nicotine group. Because we wanted to parse apart the potential dopamine $\mathrm{D}_{2}$ and $\mathrm{D}_{3}$ receptor effects, we did not use doses higher than $3 \mathrm{mg} / \mathrm{kg}$ nafadotride. In male Sprague-Dawley rats, doses higher than $3 \mathrm{mg} / \mathrm{kg}$ cause a loss of dopamine $\mathrm{D}_{3}$ receptor specificity due to increased dopamine $\mathrm{D}_{2}$ receptor binding (Audinot et al., 1998 and Levant and Vansell, 1997). These findings are similar to operant drug discrimination work in which dopamine has a minimal role in the function of nicotine as a discriminative stimulus (Corrigall and Coen, 1994, Le Foll et al., 2005, Mansbach et al., 1998, Reavill and Stolerman, 1987 and Shoaib, 1998).

Previous research with nafadotride has shown that the antagonist is behaviorally active when administered on its own to rats (e.g., Gyertyán and Sághy, 2004, Kuballa et al., 2005 and Sautel et al., 1995). There are mixed reports as to whether nafadotride doses lower than $3 \mathrm{mg} / \mathrm{kg}$ increase spontaneous locomotor activity in habituated rats (Gyertyán and Sághy, 2004 and Sautel et al., 1995). In the current research, when nafadotride was administered alone, activity was not increased above saline levels.

Nicotine administration also produces increased glutamate release throughout the striatum (McGehee et al., 1995, Schilström et al., 2000, Schilström et al., 2003 and Toth et al., 1993), allowing for the potential of glutamatergic mediation of the conditional stimulus properties of nicotine. To our knowledge, only one study has examined the effects of MPEP, an mGluR5 antagonist, on the nicotine discriminative stimulus. In that study, Zakharova et al. (2005) assessed whether pretreatment with 5.6 $\mathrm{mg} / \mathrm{kg}$ MPEP shifted the nicotine dose-effect function for rats trained with $0.6 \mathrm{mg}$ base $/ \mathrm{kg}$ nicotine. They found that MPEP partially blocked the nicotine cue only at doses lower than the training dose of nicotine, demonstrating a marginal role for metabotropic glutamate receptor type 5 activation in nicotine drug discrimination. Similarly, in the current research, $1 \mathrm{mg} / \mathrm{kg}$ MPEP partially blocked dipper entries in the $0.1 \mathrm{mg} / \mathrm{kg}$ nicotine group without reducing general chamber activity. All other decreases in conditioned responding coincided with a reduction in general activity, indicating non-specific effects of MPEP. As noted earlier, such a pattern complicates interpretation of MPEP antagonism of goal tracking. 
Interestingly, we found an increase in general activity for the $0.4 \mathrm{mg} / \mathrm{kg}$ nicotine group when pretreated with 0.3 and 1 $\mathrm{mg} / \mathrm{kg}$ MPEP. The increase did not occur in the 0.1 or $0.2 \mathrm{mg} /$ $\mathrm{kg}$ nicotine groups. MPEP administration alone did not increase chamber activity; therefore, this effect is not due to a summation of the locomotor activating effects of $0.4 \mathrm{mg} / \mathrm{kg}$ nicotine with MPEP. There is the possibility that the co-administration of nicotine with the low doses of MPEP may be antagonizing some inhibitory component of the $0.4 \mathrm{mg} / \mathrm{kg}$ nicotine dose, allowing for increased activity. Because the increase in activity was not paralleled by a change in conditioned responding, MPEP did not alter the nicotine cue at those doses, suggesting that the antagonized component of nicotine administration was specific to general chamber activity. Because MPEP did not increase conditioned responding, the proposed explanation is somewhat at odds with the nicotine generalization results described previously in which rats trained with the $0.4 \mathrm{mg} / \mathrm{kg}$ dose displayed an increase in conditioned responding when tested with $0.2 \mathrm{mg} / \mathrm{kg}$. Although we do not have activity data for the generalization portion of the current study, ongoing research in our laboratory shows that $0.4 \mathrm{mg} / \mathrm{kg}$ trained rats do not show increased activity when tested with $0.2 \mathrm{mg} / \mathrm{kg}$ nicotine. Enhancement of locomotor activity has also been demonstrated when MPEP is co-administered with phencyclidine, an $N$-methyl-D-aspartate receptor channel blocker (Henry et al., 2002, Kinney et al., 2003, Pietraszek et al., 2004 and Snell and Johnson, 1986) but not amphetamine (Pietraszek et al., 2004). The current research extends this observation to $0.4 \mathrm{mg} / \mathrm{kg}$ nicotine, suggesting a possible shared mechanism of $N$-methyl-D-aspartate receptor blockade and nicotinic acetylcholine receptor activation that is enhanced by MPEP. The 0.1 and $0.2 \mathrm{mg} / \mathrm{kg}$ nicotine trained rats did not show this effect of MPEP pretreatment indicating that $0.4 \mathrm{mg} / \mathrm{kg}$ nicotine may have somewhat different cellular processes than the lower doses. Further research into the locomotor enhancing effects of metabotropic glutamate receptor type 5 blockade is necessary before any conclusions can be drawn concerning MPEP-nicotine interactions.

In the present study, MK-801 pretreatment resulted in decreased conditioned responding evoked by nicotine without a corresponding decrease in general chamber activity, implicating $N$-methyl-D-aspartate receptors in the conditional stimulus effects of nicotine. Before this conclusion can be accepted, several alternative explanations for the behavioral effects of MK- 801 must be addressed. One possible mechanism by which MK-801 may exert its effect on conditioned responding is that $N$-methyl-D-aspartate receptor activation may be necessary for retrieval of the neural representation of a nicotine cue. Another possible explanation is that the co-administration of MK-801 with nicotine may create a drug state that is different from that in which the nicotine-sucrose association was learned (see Tzschentke and Schmidt, 2000; see also Wolf, 1998). For this latter possibility, MK- 801 has served as an effective discriminative stimulus in operant drug discrimination work (Corbett, 1995, Smith et al., 1999 and Zajaczkowski et al., 1996), and therefore, in our study, the addition of MK-801 to nicotine may be creating a distinct cue different from that of nicotine alone. These two alternative accounts, however, are strained by the recent finding that MK-801 did not block nicotine-appropriate responding in the Zakharova et al. (2005) study using a 2-lever drug discrimination task. If MK-801 was blocking retrieval or creating a distinct drug state when combined with nicotine, these authors should have observed less responding on the nicotine-appropriate lever. Although the training dose of nicotine in that study $(0.6 \mathrm{mg} / \mathrm{kg})$ was markedly higher than any used in the current research $(0.1-0.4 \mathrm{mg} / \mathrm{kg})$, the dose of MK-801 was also much higher (up to $0.6 \mathrm{mg} / \mathrm{kg}$ ).

MK-801 also acts as a nicotinic acetylcholine receptor channel blocker (Amador and Dani, 1991, Buisson and Bertrand, 1998 and Ramoa et al., 1990) and could be producing the decrease in conditioned responding via that mechanism. Because the nicotine conditional stimulus has been blocked by mecamylamine (Besheer et al., 2004), the effects of MK801 pretreatment are consistent with previous findings and allow for the potential of nicotinic acetylcholine receptor action of MK-801 in the current research. This action of MK801 in a behavioral paradigm is highly unlikely, however, as MK-801 has a 40 - to 100 -fold selectivity for $N$-methyl-D-aspartate receptors over nicotinic acetylcholine receptors (Amador and Dani, 1991, Huettner and Bean, 1988 and Löscher et al., 2003). The possibility is further strained by the finding that there is a demonstrated difference between the abilities of MK-801 and mecamylamine to disrupt behavioral effects of nicotine (Zakharova et al., 2005).

Nicotine has been previously established to have associative properties beyond that of an unconditioned stimulus or reinforcer (Besheer et al., 2004, Bevins and Palmatier, 2004 and Wilkinson et al., 2006b). The current study further characterized the conditional stimulus properties of nicotine by showing that a dose of nicotine that has limited unconditioned effects (cf. Bevins and Palmatier, 2003, Bevins et al., 2001 and Iwamoto and Williamson, 1984) readily serves as robust conditional stimulus. Additionally, the current study shows the first example of a pharmacological dissociation between the roles of nicotine as a discriminative stimulus versus nicotine as a conditional stimulus. $N$-methyl-D-aspartate receptor antagonism by MK801 blocked the nicotine cue in the present appetitive Pavlovian drug discrimination task but has not blocked the nicotine cue in an operant drug discrimination paradigm (Zakharova et al., 2005), indicating that activation of $N$-methyl-D-aspartate receptors may be a component of what allows nicotine to function as a conditional stimulus. Although caution must be taken when making direct comparisons between studies using different training and test doses of drugs, it is clear that the dissociation highlights the potential for mechanistic differences between the types of nicotine cues. This finding also suggests that not only are there associative properties underlying human tobacco use beyond the current conceptualization, but that there may be additional pharmacological components that contribute to the prevalence of worldwide nicotine consumption that have yet to be fully explored (Bevins and Palmatier, 2004 and Mackay and Eriksen, 2002). 


\section{Acknowledgements}

We thank Jamie L. Wilkinson for her assistance with the rats. We also thank Anthony S. Rauhut, Jessica D. Linkugel, and Rachel D. Penrod for their thoughtful comments on earlier versions of this report. The research and R. A. Bevins were supported by United States Public Health Service grant DA018114. All MED-PC programs used in the present article are available upon request. Correspondence related to this article should be addressed to Rick A. Bevins, Department of Psychology, University of Nebraska-Lincoln, Lincoln NE USA 68588-0308, or e-mail rbevins1@unl.edu.

\section{References}

Amador, M., Dani, J.A., 1991. MK-801 inhibition of nicotinic acetylcholine receptor channels. Synapse 7, 207-215.

Andersen, P.H., Grønvald, F.C., 1986. Specific binding of 3H-SCH 23390 to dopamine D1 receptors in vivo. Life Sci. 38, 1507-1514.

Ascher, P., Nowak, L., 1988. The role of divalent cations in the $N$-methylD-aspartate responses of mouse central neurons in culture. J. Physiol. (Lond.) 399, 247-266.

Asghar, K., Roth, L.J., 1971. Entry and distribution of hexamethonium in the central nervous system. Biochem. Pharmacol. 20, 2787-2795.

Audinot, V., Newman-Tancredi, A., Gobert, A., Rivet, J.M., Brocco, M., Lejeune, F., Gluck, L., Desposte, I., Bervoets, K., Dekeyne, A., Millan, M.J., 1998. A comparative in vitro and in vivo pharmacological characterization of the novel dopamine D3 receptor antagonists (+)-S 14297, nafadotride, GR 103,691 and U 99194. J. Pharmacol. Exp. Ther. 287, 187197.

Besheer, J., Palmatier, M.I., Metschke, D.M., Bevins, R.A., 2004. Nicotine as a signal for the presence or absence of sucrose reward: a Pavlovian drug appetitive conditioning preparation in rats. Psychopharmacology 172, $108-117$.

Bespalov, A.Y., Dravolina, O.A., Sukhanov, I., Zakharova, E., Blokhina, E., Zvartau, E., Danysz, W., van Heeke, G., Markou, A., 2005. Metabotropic glutamate receptor (mGluR5) antagonist MPEP attenuated cue-and schedule-induced reinstatement of nicotine self-administration behavior in rats. Neuropharmacology 49, 167-178.

Bevins, R.A., Palmatier, M.I., 2003. Nicotine-conditioned locomotor sensitization in rats: assessment of the US-preexposure effect. Behav. Brain Res. $14,365-374$.

Bevins, R.A., Palmatier, M.I., 2004. Extending the role of associative learning processes in nicotine addiction. Behav. Cogn. Neurosci. Rev. 3, 143158.

Bevins, R.A., Besheer, J., Pickett, K.S., 2001. Nicotine-conditioned locomotor activity in rats: dopaminergic and GABAergic influences on conditioned expression. Pharmacol. Biochem. Behav. 68, 135-145.

Bevins, R.A., Eurek, S., Besheer, J., 2005. Timing of conditioned responding in a nicotine locomotor conditioning preparation: manipulations of the temporal arrangement between context cues and drug administration. Behav. Brain Res. 159, 135-143.

Bevins, R.A., Wilkinson, J.L., Palmatier, M.I., Siebert, H.L., Wiltgen, S.M., 2006. Characterization of nicotine's ability to serve as a negative feature in a Pavlovian appetitive conditioning task in rats. Psychopharmacology 184, 470-481.

Boakes, R.A., 1977. Performance on learning to associate a stimulus with positive reinforcement. In: Davis, H., Hurwitz, H.M.B. (Eds.), OperantPavlovian Interactions. Erlbaum, NJ, pp. 67-97.

Buisson, B., Bertrand, D., 1998. Open-channel blockers at the human alpha4beta2 neuronal nicotinic acetylcholine receptor. Mol. Pharmacol. 53, 555-563.
Chance, W.T., Murfin, D., Krynock, G.M., Rosecrans, J.A., 1977. A description of the nicotine stimulus and tests of its generalization to amphetamine. Psychopharmacology 55, 19-26.

Corbett, R., 1995. Clozapine but not haloperidol antagonizes an MK-801 discriminative stimulus cue. Pharmacol. Biochem. Behav. 51, 561-564.

Corrigall, W.A., Coen, K.M., 1994. Dopamine mechanisms play at best a small role in the nicotine discriminative stimulus. Pharmacol. Biochem. Behav. 48, 817-820.

Corrigall, W.A., Coen, K.M., Adamson, K.L., 1994. Self-administered nicotine activates the mesolimbic dopamine system through the ventral tegmental area. Brain Res. 653, 278-284.

Desai, R., Barber, D.J., Terry, P., 2003. Dopaminergic and cholinergic involvement in the discriminative stimulus effects of nicotine and cocaine in rats. Psychopharmacology 167, 335-343.

Di Chiara, G., Imperato, A., 1988. Drugs abused by humans preferentially increase synaptic dopamine concentrations in the mesolimbic system of freely moving rats. Proc. Natl. Acad. Sci. U. S. A. 85, 5274-5278

Farwell, B.J., Ayres, J.J.B., 1979. Stimulus-reinforcer and response-reinforcer relations in the control of conditioned appetitive headpoking ("goal tracking") in rats. Learn. Motiv. 10, 295-312.

Frey, P.W., Sears, R.J., 1978. Model of conditioning incorporating the Rescorla- Wagner associative axiom, a dynamic attention process, and a catastrophe rule. Psychol. Rev. 85, 321-340.

Fudala, P.J., Teoh, K.W., Iwamoto, E.T., 1985. Pharmacologic characterization of nicotine-induced conditioned place preference. Pharmacol. Biochem. Behav. 22, 237-241.

Gasior, M., Shoaib, M., Yasar, S., Jaszyna, M., Goldberg, S.R., 1999. Acquisition of nicotine discrimination and discriminative stimulus effects of nicotine in rats chronically exposed to caffeine. J. Pharmacol. Exp. Ther. 288, 1053-1073.

Gasior, M., Jaszyna, M., Peters, J., Goldberg, S.R., 2000. Changes in the ambulatory activity and discriminative stimulus effects of psychostimulant drugs in rats chronically exposed to caffeine: effect of caffeine dose. J. Pharmacol. Exp. Ther. 295, 1101-1111.

Gasior, M., Jaszyna, M., Munzar, P., Witkin, J.M., Goldberg, S.R., 2002. Caffeine potentiates the discriminative-stimulus effects of nicotine in rats. Psychopharmacology 162, 385-395.

Gasparini, F., Lingenhöhl, K., Stoehr, N., Flor, P.J., Heinrich, M., Vranesic, I., Biollaz, M., Allgeier, H., Heckendorn, R., Urwyler, S., Varney, M.A., Johnson, E.C., Hess, S.D., Rao, S.P., Sacaan, A.I., Santori, E.M., Veliçelebi, G., Kuhn, R., 1999. 2-Methyl-6-(phenylethynyl)-pyridine (MPEP), a potent, selective and systemically active mGlu5 receptor antagonist. Neuropharmacology 38, 1493-1503.

Gyertyán, I., Sághy, K., 2004. Effects of dopamine D3 receptor antagonists on spontaneous and agonist-reduced motor activity in NMRI mice and Wistar rats: comparative study with nafadotride, U 99194A and SB 277011. Behav. Pharmacol. 15, 253-262.

Hall, H., Köhler, C., Gawell, L., 1985. Some in vitro receptor binding properties of $[3 \mathrm{H}]$ eticlopride, a novel substituted benzamide, selective for dopamineD2 receptors in the rat brain. Eur. J. Pharmacol. 111, 191-199.

Halliwell, R.F., Peters, J.A., Lambert, J.J., 1989. The mechanism of action and pharmacological specificity of the anticonvulsant NMDA antagonist MK-801: a voltage clamp study on neuronal cells in culture. Br. J. Pharmacol. 96, 480-494.

Harrison, A.A., Gasparini, F., Markou, A., 2002. Nicotine potentiation of brain stimulation reward reversed by $\mathrm{DH} \beta \mathrm{E}$ and $\mathrm{SCH} 23390$, but not by eticlopride, LY 314582 or MPEP in rats. Psychopharmacology 160, 5666.

Henry, S.A., Lehmann-Masten, V., Gasparini, F., Geyer, M.A., Markou, A., 2002. The mGluR5 antagonist MPEP, but not the mGluR2/3 agonist LY314582, augments PCP effects on prepulse inhibition and locomotor activity. Neuropharmacology 43, 1199-1209.

Huettner, J.E., Bean, B.P., 1988. Block of $N$-methyl-D-aspartate-activated current by the anticonvulsant MK-801: selective binding to open channels. 
Proc. Natl. Acad. Sci. U. S. A. 85, 1307-1311.

Hyttel, J., Arnt, J., 1987. Characterization of binding of 3H-SCH 23390 to dopamine D-1 receptors. Correlation to other D-1 and D-2 measures and effect of selective lesions. J. Neural Transm. 68, 171-189.

Imperato, A., Mulas, A., Di Chiara, G., 1986. Nicotine preferentially stimulates dopamine release in the limbic system of freely moving rats. Eur. J. Pharmacol. 132, 337-338.

Iorio, L.C., Barnett, A., Leitz, F.H., Houser, V.P., Korduba, C.A., 1983. SCH 23390 , a potential benzazepine antipsychotic with unique interactions on dopaminergic systems. J. Pharmacol. Exp. Ther. 226, 462-468.

Iwamoto, E.T., Williamson, E.C., 1984. Nicotine-induced taste aversion: characterization and preexposure effect in rats. Pharmacol. Biochem. Behav. 21, 527-532.

Kenny, P.J., Paterson, N.E., Boutrel, B., Semenova, S., Harrison, A.A., Gasparini, F., Koob, G.F., Skoubis, P.D., Markou, A., 2003. Metabotropic glutamate 5 receptor antagonist MPEP decreased nicotine and cocaine selfadministration but not nicotine and cocaine-induced facilitation of brain reward function in rats. Ann. N.Y. Acad. Sci. 1003, 415-418.

Kinney, G.G., Burno, M., Campbell, U.C., Hernandez, L.M., Rodriguez, D., Bristow, L.J., Conn, P.J., 2003. Metabotropic glutamate subtype 5 receptors modulate locomotor activity and sensorimotor gating in rodents. J. Pharmacol. Exp. Ther. 306, 116-123.

Kiss, J.P., Tóth, E., Lajtha, A., Vizi, E.S., 1994. NMDA receptors are not involved in the MK-801-induced increase of striatal dopamine release in rat: a microdialysis study. Brain Res. 641, 145-148.

Köhler, C., Hall, H., Gawell, L., 1986. Regional in vivo binding of the substituted benzamide $[3 \mathrm{H}]$ eticlopride in the rat brain: evidence for selective labeling of dopamine receptors. Eur. J. Pharmacol. 120, 217-226.

Kuballa, G., Nowak, P., Labus, Ł., Bortel, A., Dąbrowska, J., Swoboda, M., Kwieciński, A., Kostrzewa, R.M., Brus, R., 2005. Central effects of nafadotride, a dopamine D3 receptor antagonist, in rats. Comparison with haloperidol and clozapine. Pharmacol. Reprod. 57, 161-169.

Kumar, R., Pratt, J.A., Stolerman, I.P., 1983. Characteristics of conditioned taste aversion produced by nicotine in rats. Br. J. Pharmacol. 79, 245253.

Le Foll, B., Schwartz, J.-C., Sokoloff, P., 2003. Disruption of nicotine conditioning by dopamine D3 receptor ligands. Mol. Psychiatry 8, 225-230.

Le Foll, B., Sokoloff, P., Stark, H., Goldberg, S.R., 2005. Dopamine D3 receptor ligands block nicotine-induced conditioned place preferences through a mechanism that does not involve discriminative-stimulus or antidepressant-like effects. Neuropsychopharmacology 30, 720-730.

Levant, B., Vansell, N.R., 1997. In vivo occupancy of D2 dopamine receptors by nafadotride. Neuropsychopharmacology 17, 67-71.

Löscher, W., Potschka, H., Walz, P., Danysz, W., Parsons, C.G., 2003. Are neuronal nicotinic receptors a target for antiepileptic drug development? Studies in different seizure models in mice and rats. Eur. J. Pharmacol. 466, 99-111.

Mackay, J., Eriksen, M., 2002. Tobacco atlas. London, Hanway Press, World Health Organization.

Mansbach, R.S., Rovetti, C.C., Freedland, C.S., 1998. The role of monoamine neurotransmitter systems in the nicotine discriminative stimulus. Drug Alcohol Depend. 52, 125-134.

McGehee, D.S., Heath, M.J.S., Gelber, S., Devay, P., Role, L.W., 1995. Nicotine enhancement of fast excitatory synaptic transmission in CNS by presynaptic receptors. Science 269, 1692-1696.

Morrison, C.F., Stephenson, J.A., 1969. Nicotine injections as the conditioned stimulus in discrimination learning. Psychopharmacologia 15, 351-360.

National Research Council, 1996. Guide for the Care and Use of Laboratory Animals. National Academy Press, Washington, DC.

Nisell, M., Nomikos, G.G., Svensson, T.H., 1994. Infusion of nicotine in the ventral tegmental area or the nucleus accumbens of the rat differentially affects accumbal dopamine release. Pharmacol. Toxicol. 75, 348-352.

Palmatier, M.I., Peterson, J.L., Wilkinson, J.L., Bevins, R.A., 2004. Nicotine serves as a feature-positive modulator of Pavlovian appetitive conditioning in rats. Behav. Pharmacol. 15, 183-194.

Palmatier, M.I., Wilkinson, J.L., Metschke, D.M., Bevins, R.A., 2005. Stimulus properties of nicotine, amphetamine, and chlordiazepoxide as positive features in a Pavlovian appetitive discrimination task in rats. Neuropsychopharmacology 30, 731-741.

Papke, R.L., Sanberg, P.R., Shytle, R.D., 2001. Analysis of mecamylamine stereoisomers on human nicotinic receptor subtypes. J. Pharmacol. Exp. Ther. 297, 646-656.

Paterson, N.E., Semenova, S., Gasparini, F., Markou, A., 2003. The mGluR5 antagonist MPEP decreases nicotine self-administration in rats and mice. Psychopharmacology 167, 257-264.

Pavlov, I.P., 1927. Conditioned Reflexes. Oxford University Press, London.

Pidoplichko, V.I., Noguchi, J., Areaola, O.O., Liang, Y., Peterson, J., Ahang, T., Dani, J.A., 2004. Nicotinic cholinergic synaptic mechanisms in the ventral tegmental area contribute to nicotine addiction. Learn. Mem. 11, 60-69.

Pietraszek, M., Rogóż, Z., Wolfarth, S., Ossowska, K., 2004. Opposite influence of MPEP, an mGluR5 antagonist, on the locomotor hyperactivity induced by PCP and amphetamine. J. Physiol. Pharmacol. 55, 587-593.

Pontieri, F.E., Tanda, G., Orzi, F., Di Chiara, G., 1996. Effects of nicotine on the nucleus accumbens and similarity to those of addictive drugs. Nature $382,255-257$.

Pratt, J.A., Stolerman, I.P., Garcha, H.S., Giardini, V., Feyerabend, C., 1983. Discriminative stimulus properties of nicotine: further evidence for mediation at a cholinergic receptor. Psychopharmacology 81, 54-60.

Ramoa, A.S., Alkondon, M., Aracava, Y., Irons, J., Lunt, G.G., Deshpande, S.S., Wonnacott, S., Aronstam, R.S., Alburquerque, E.X., 1990. The anticonvulsant MK-801 interacts with peripheral and central nicotinic acetylcholine receptor ion channels. J. Pharmacol. Exp. Ther. 254, 71-82.

Reavill, C., Stolerman, I.P., 1987. Interaction of nicotine with dopaminergic mechanisms assessed through drug discrimination and rotational behaviour in rats. J. Psychopharmacol. 1, 264-273.

Reid, M.S., Fox, L., Ho, L.B., Berger, S.P., 2000. Nicotine stimulation of extracellular glutamate levels in the nucleus accumbens: neuropharmacological characterization. Synapse 35, 129-136.

Rescorla, R.A., 1988. Behavioral studies of pavlovian conditioning. Annu. Rev. Neurosci. 11, 329-352.

Rescorla, R.A., Wagner, A.R., 1972. A theory of Pavlovian conditioning: variations in the effectiveness of reinforcement and nonreinforcement. In: Black, A.H., Prokasy, W.F. (Eds.), Classical Conditioning II: Current Research and Theory. Meredith Corporation, New York, pp. 64-99.

Sautel, F., Griffon, N., Sokoloff, P., Schwartz, J.-C., Launay, C., Simon, P., Costentin, J., Schoenfelder, A., Garrido, F., Mann, A., Wermuth, C.G., 1995. Nafadotride, a potent preferential dopamine D3 receptor antagonist, activates locomotion in rodents. J. Pharmacol. Exp. Ther. 275, 12391246.

Schilström, B., Fagerquist, M.V., Zhang, X., Hertel, P., Panagis, G., Nomikos, G.G., Svensson, T.H., 2000. Putative role of presynaptic $\alpha 7^{*}$ nicotinic receptors in nicotine stimulated increases of extracellular levels of glutamate and aspartate in the ventral tegmental area. Synapse 38, 375-383.

Schilström, B., Rawal, N., Mameli-Engvall, M., Nomikos, G.G., Svensson, T.H., 2003. Dual effects of nicotine on dopamine neurons mediated by different nicotinic receptor subtypes. Int. J. Neuropsychopharmacol. 6, 1-11.

Schilström, B., Mameli-Engvall, M., Rawal, N., Grillner, P., Jardemark, K., Svensson, T.H., 2004. Nitric oxide is involved in nicotine-induced burst firing of rat ventral tegmental area dopamine neurons. Neuroscience 125 , 957-964.

Shim, I., Kim, H.-T., Kim, Y.-H., Chun, B.-G., Hahm, D.-H., Lee, E.H., Kim, S.E., Lee, H.-J., 2002. Role of nitric oxide synthase inhibitors and NMDA receptor antagonist in nicotine-induced behavioral sensitization in the rat. Eur. J. Pharmacol. 443, 119-124.

Shoaib, M., 1998. Is dopamine important in nicotine dependence? J. Physiol. 92, 229-233. 
Shoaib, M., Stolerman, I.P., 1992. MK801 attenuates behavioural adaptation to chronic nicotine administration in rats. Br. J. Pharmacol. 105, 514-515.

Shoaib, M., Benwell, M.E.M., Akbar, M.T., Stolerman, I.P., Balfour, D.J.K., 1994a. Behavioural and neurochemical adaptations to nicotine in rats: influence of NMDA antagonists. Br. J. Pharmacol. 111, 1073-1080.

Shoaib, M., Stolerman, I.P., Kumar, R.C., 1994b. Nicotine-induced place preferences following prior nicotine exposure in rats. Psychopharmacology $113,445-452$.

Shoaib, M., Schindler, C.W., Goldberg, S.R., Pauly, J.R., 1997. Behavioural and biochemical adaptations to nicotine in rats: influence of MK801, an NMDA receptor antagonist. Psychopharmacology 134, 121-130.

Smith, J.A., Boyer-Millar, C., Goudie, A.J., 1999. Does MK-801 discrimination constitute an animal model of schizophrenia useful for detecting atypical antipsychotics? Pharmacol. Biochem. Behav. 64, 429-433.

Snell, L.D., Johnson, K.M., 1986. Characterization of the inhibition of excitatory amino acid-induced neurotransmitter release in the rat striatum by phencyclidine-like drugs. J. Pharmacol. Exp. Ther. 238, 938-946.

Stolerman, I.P., 1989. Discriminative stimulus effects of nicotine in rats trained under different schedules of reinforcement. Psychopharmacology 97, 131-138

Stolerman, I.P., Garcha, H.S., Pratt, J.A., Kumar, R., 1984. Role of training dose in discrimination of nicotine and related compounds in rats. Psychopharmacology 84, 413-419.

Stolerman, I.P., Chandler, C.J., Garcha, H.S., Newton, J.M., 1997. Selective antagonism of behavioural effects of nicotine by dihydro- $\beta$-erythroidine in rats. Psychopharmacology 129, 390-397.

Sziráki, I., Sershen, H., Benuck, M., Hashim, A., Lajtha, A., 1998. Receptor systems participating in nicotine-specific effects. Neurochem. Int. 33, 445-457.

Sziráki, I., Sershen, H., Hashim, A., Lajtha, A., 2002. Receptors in the ventral tegmental area mediating nicotine-induced dopamine release in the nucleus accumbens. Neurochem. Res. 27, 253-261.

Tang, L., Todd, R.D., Heller, A., O’Malley, K.L., 1994. Pharmacological and functional characterization of D2, D3 and D4 dopamine receptors in fibroblast and dopaminergic cell lines. J. Pharmacol. Exp. Ther. 268, 495-502.
Tessari, M., Pilla, M., Andreoli, M., Hutcheson, D.M., Heidbreder, C.A., 2004. Antagonism at metabotropic glutamate 5 receptors inhibits nicotine-and cocaine-taking behaviours and prevents nicotine-triggered relapse to nicotine-seeking. Eur. J. Pharmacol. 499, 121-133.

Toth, E., Sershen, H., Hashim, A., Vizi, E.S., Lajtha, A., 1992. Effect of nicotine on extracellular levels of neurotransmitters assessed by microdialysis in various brain regions: role of glutamic acid. Neurochem. Res. 17, 265-271.

Toth, E., Vizi, E.S., Lajtha, A., 1993. Effect of nicotine on levels of extracellular amino acids in regions of the rat brain in vivo. Neuropharmacology $32,827-832$.

Tzschentke, T.M., Schmidt, W.J., 2000. Blockade of behavioral sensitization by MK-801: fact or artifact? Psychopharmacology 151, 142-151.

Walter, S., Kuschinsky, K., 1989. Conditioning of nicotine effects on motility and behaviour in rats. Naunyn-Schmiedeberg's Arch. Pharmacol. 339, 208-213

Wilkinson, J.L., Herrman, L., Palmatier, M.I., Bevins, R.A., 2006a. Rats' novel object interaction as a measure of environmental familiarity. Learn. Motiv. 37, 131-148.

Wilkinson, J.L., Murray, J.E., Li, C., Wiltgen, S.M., Penrod, R.D., Berg, S.A., Bevins, R.A., 2006b. Interoceptive Pavlovian conditioning with nicotine as the conditional stimulus varies as function of number of conditioning trials and unpaired sucrose deliveries. Behav. Pharmacol. 17, 161-172.

Wolf, M.E., 1998. The role of excitatory amino acids in behavioral sensitization to psychomotor stimulants. Prog. Neurobiol. 54, 679-720.

Wong, E.H.F., Kemp, J.A., Priestley, T., Knight, A.R., Woodruff, G.N., Iversen, L.L., 1986. The anticonvulsant MK-801 is a potent $N$-methyl-Daspartate antagonist. Proc. Natl. Acad. Sci. U. S. A. 83, 7104-7108.

Zajaczkowski, W., Moryl, E., Papp, M., 1996. Discriminative stimulus effects of the NMDA receptor antagonists MK-801 and CGP 37849 in rats. Pharmacol. Biochem. Behav. 55, 163-168.

Zakharova, E.S., Danysz, W., Bespalov, A.Y., 2005. Drug discrimination analysis of NMDA receptor channel blockers as nicotinic receptor antagonists in rats. Psychopharmacology 179, 128-135. 